Atmos. Chem. Phys., 21, 14019-14037, 2021

https://doi.org/10.5194/acp-21-14019-2021

(C) Author(s) 2021. This work is distributed under

the Creative Commons Attribution 4.0 License.

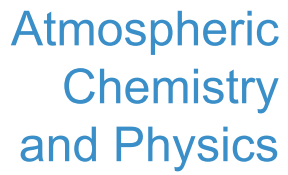

(c) (P)

\title{
Exceptional loss in ozone in the Arctic winter/spring of 2019/2020
}

\author{
Jayanarayanan Kuttippurath ${ }^{1}$, Wuhu Feng ${ }^{2,3}$, Rolf Müller ${ }^{4}$, Pankaj Kumar ${ }^{1}$, Sarath Raj ${ }^{1}$, \\ Gopalakrishna Pillai Gopikrishnan ${ }^{1}$, and Raina Roy ${ }^{5}$ \\ ${ }^{1}$ CORAL, Indian Institute of Technology Kharagpur, Kharagpur-721302, India \\ ${ }^{2}$ National Centre for Atmospheric Science, University of Leeds, Leeds, LS2 9PH, UK \\ ${ }^{3}$ School of Earth and Environment, University of Leeds, Leeds, LS2 9JT, UK \\ ${ }^{4}$ Forschungszentrum Jülich GmbH (IEK-7), 52425 Jülich, Germany \\ ${ }^{5}$ Department of Physical Oceanography, Cochin University of Science and Technology, Kochi, India
}

Correspondence: Jayanarayanan Kuttippurath (jayan@coral.iitkgp.ac.in)

Received: 23 December 2020 - Discussion started: 24 February 2021

Revised: 28 July 2021 - Accepted: 9 August 2021 - Published: 21 September 2021

\begin{abstract}
Severe vortex-wide ozone loss in the Arctic would expose both ecosystems and several millions of people to unhealthy ultraviolet radiation. Adding to these worries, and extreme events as the harbingers of climate change, exceptionally low ozone with column values below $220 \mathrm{DU}$ occurred over the Arctic in March and April 2020. Sporadic occurrences of low ozone with less than $220 \mathrm{DU}$ at different regions of the vortex for almost 3 weeks were found for the first time in the observed history in the Arctic. Furthermore, a large ozone loss of about 2.0-3.4 ppmv triggered by an unprecedented chlorine activation (1.5-2.2 ppbv) matching the levels occurring in the Antarctic was also observed. The polar processing situation led to the first-ever appearance of loss saturation in the Arctic. Apart from these, there were also ozone-mini holes in December 2019 and January 2020 driven by atmospheric dynamics. The large loss in ozone in the colder Arctic winters is intriguing and demands rigorous monitoring of the region.
\end{abstract}

\section{Introduction}

Apart from its significance of shielding us from the harmful ultraviolet (UV) radiation reaching the surface of earth, stratospheric ozone is a key component in regulating the climate (e.g. Riese et al., 2012). Changes in stratospheric ozone are always a big concern for both public health and climate (WMO, 2018; Bais et al., 2019). Due to unbridled emissions of ozone-depleting substances (ODSs) to the atmosphere since the 1930s, stratospheric chlorine peaked in the polar stratosphere in the early 2000s (Newman et al., 2007; Engel et al., 2018; WMO, 2018; Bais et al., 2018). The first signatures of polar ozone loss appeared over Antarctica by the late 1970s (Chubachi et al., 1984; Farman et al., 1985), and it peaked to saturation levels in the late 1980s due to already high levels of stratospheric chlorine (Kuttippurath et al., 2018). Recent studies have demonstrated the effectiveness of the Montreal Protocol and its amendments and adjustments in reducing halogen gases, with a corresponding positive trend in ozone in Antarctica (Salby et al., 2011; Kuttippurath et al., 2013; Solomon et al., 2016; Chipperfield et al., 2017) and in northern midlatitudes (Steinbrecht et al., 2003; Nair et al., 2015; Weber et al., 2018). However, a positive trend in the Arctic ozone is not reported yet, possibly because of the large dynamically driven inter-annual variability of ozone there (Kivi et al., 2007; WMO, 2018).

Antarctic winters are very cold, and the ozone hole has been a common feature of these winters since the late 1970s. There were winters with very low stratospheric temperatures with a stronger vortex that showed relatively larger loss in ozone, such as the winters of 1996, 2000, 2003, 2006, and 2015 (Bodeker et al., 2005; Chipperfield et al., 2017). There were also winters with higher temperatures and smaller ozone losses as in the case of 1998, 2002, 2012, and 2019 (Müller et al., 2008; de Laat and van Weele, 2011; Kuttippurath et al., 2015). Yet, the inter-annual variability of ozone loss in the Antarctic has been very small in recent decades. On the other hand, colder winters with large losses of ozone (e.g. > 1.5 ppmv of loss) are rare in the Arctic (Rex et al., 2004; von der Gathen et al., 2021). The ozone loss de- 
rived from satellite and ozonesonde measurements show that most winters have ozone loss in the range of $0.5-1.5 \mathrm{ppmv}$, and extremely cold winters showed large loss of about 1.52.0 ppmv (Manney et al., 2003; Kuttippurath et al., 2013; Livesey et al., 2015). Similarly, ground-based measurements show about $15 \%-20 \%$ of loss in most Arctic winters, but the winters of 1995, 1996, 2000, 2005, and 2011 were very cold with a large loss of ozone of up to $25 \%-30 \%$ (Goutail et al., 2005; Pommereau et al., 2018). However, these ozone loss values are still smaller than the $40 \%-55 \%$ loss occurrence in the Antarctic (Kuttippurath et al., 2013; Pommereau et al., 2018).

The Arctic vortex is relatively short-lived (i.e. 3 to 4 months). The vortex normally strengthens by mid-December or early January and dissipates by mid-March. Major and minor warmings are common features of Arctic winters. The Arctic vortex in any winter would be frequently disturbed by planetary waves that emanate from the troposphere. In general, planetary wave numbers 1,2 , and 3 are mostly responsible for the momentum transfer to the stratosphere. This dynamical activity would increase the temperature in the lower stratosphere and trigger stratospheric warmings. The warmings can be minor or major, depending on the strength of wave activity, increasing the polar temperature, and eventually disturbing the polar vortex. The vortex can be distorted, displaced, elongated, and even split in two in accordance with the potency of momentum imparted by the waves. When the polar vortex is disturbed, the ozone loss will be smaller and the final warming can be as early as in late February or early March, as for many Arctic winters (e.g. Manney et al., 2003; Kuttippurath et al., 2012; Goutail et al., 2015). However, the vortex dissipates and chemical ozone loss terminates when a major warming occurs there. In an earlier study, Kuttippurarth et al. (2012) observed an increasing trend in major warmings, and ozone loss is found to be proportional to the timing of the major warmings, as early winter warmings stop polar stratospheric cloud (PSC) formation (i.e. stop the action of heterogeneous chemistry) because of the higher temperatures. This situation limits the activated chlorine available for ozone loss and results in a smaller loss in warm Arctic winters. Since 1979, during the satellite era, there have been two extreme winters with a large loss of ozone in the Arctic: 2005 and 2011 (Coy et al., 1997; Feng et al., 2007; Hurwitz et al., 2011). The occurrence of extreme events is a feature of climate change (e.g. IPCC, 2007). Therefore, the extremely cold winters with a large loss in ozone could also be a harbinger of climate change. Previous studies have postulated that the cold winters will get even colder with a large loss in ozone (Sinnhuber et al., 2000; Rex et al., 2004; Chipperfield et al., 2005; Rieder and Polvani, 2013; von der Gathen et al., 2021). Analyses of the past colder Arctic winters indicate that it is likely that the colder winters may experience a large loss in ozone, as in the case of 2005, 2016, and 2011. There are already studies on this winter discussing the ozone loss and meteorology (Man- ney et al., 2020; Wohltmann et al., 2020; Rao and Grafinkel, 2020; Weber et al., 2021; Inness et al., 2020; Wilka et al., 2021; Grooß and Müller, 2021; von der Gathen et al., 2021; Feng et al., 2021). However, in this study, we use different datasets, various ozone loss estimate methods, and several parameters together to study the polar processing and ozone loss in the Arctic winter of 2020. This is particularly important as the winter was very cold in the stratosphere, with the largest ozone loss in the observational record, and it experienced total column ozone (TCO) values below 220 DU for several days in the vortex.

\section{Data and methods}

We have used the v4.2 ozone, $\mathrm{ClO}, \mathrm{HNO}_{3}$ and $\mathrm{N}_{2} \mathrm{O}$ data from the Microwave Limb Sounder (MLS) (Livesey et al., 2020) and the v2.5 ozone profile data from the Ozone Mapping and Profiler Suite (OMPS) (Deland, 2017). The total column ozone (TCO) measurements from the following satellite instruments are also considered: the Ozone Monitoring Instrument (OMI, DOAS v003) (Veefkind, 2012), OMPS (v2.1) (Jaross, 2017), and the Global Ozone Monitoring Experiment (GOME) 2 (GDP4.8) (Valks et al., 2014). In addition, we have used the ozonesonde and Brewer ozone measurements from the Arctic stations at Alert $\left(62.34^{\circ} \mathrm{N}, 82.49^{\circ} \mathrm{W}\right)$ and Eureka $\left(79.99^{\circ} \mathrm{N}, 85.90^{\circ} \mathrm{W}\right)$ (WMO/GAW UV Radiation Monitoring Community). Furthermore, we have taken the reanalyses data from Modern-Era Retrospective analysis for Research and Applications (MERRA)-2 (GMAO, 2015) for the analysis of meteorology and ozone.

These TCO measurements have an uncertainty of $2 \%-$ $5 \%$. The ozone and other trace gas profiles are provided in pressure coordinates that are converted to isentropic coordinates using the temperature data from the same satellite, except for OMPS, for which the temperature data are taken from ERA5. We use the European Centre for MediumRange Weather Forecasts (ECMWF) Reanalyses ERA5 potential vorticity $(\mathrm{PV})$ on a $1^{\circ} \times 1^{\circ}$ grid to determine the vortex edge. The PV data are also converted to isentropic coordinates using the ERA5 temperature data. We computed the equivalent latitude at each isentropic level at $5 \mathrm{~K}$ intervals from 350 to $800 \mathrm{~K}$, which is then used to compute the vortex edge using the Nash et al. (1996) criterion. We use measurements inside the polar vortex for the ozone loss analysis. The missing values in satellite measurements were filled with linear interpolation.

We have taken ozone, $\mathrm{ClO}, \mathrm{HNO}_{3}$, and $\mathrm{N}_{2} \mathrm{O}$ from the Aura MLS measurements. The ozone measurements at $240 \mathrm{GHz}$ have a vertical resolution of $2-3 \mathrm{~km}$, a vertical range of $261-0.02 \mathrm{hPa}$, and an accuracy of $0.1-0.4 \mathrm{ppmv}$. The vertical range of $\mathrm{HNO}_{3}$ measurements is $215-1.5 \mathrm{hPa}$, and the vertical resolution is $2-4 \mathrm{~km}$, with an accuracy of $0.1-2.4 \mathrm{ppbv}$, depending on altitude. The $\mathrm{N}_{2} \mathrm{O}$ measurements are available for the $68-0.46 \mathrm{hPa}$ vertical range, and $68 \mathrm{hPa}$ is roughly 
equivalent to the $400 \mathrm{~K}$ isentropic level. The data were extrapolated up to $350 \mathrm{~K}$ by performing exponential fitting to the $\mathrm{N}_{2} \mathrm{O}$ vertical distribution at $400-600 \mathrm{~K}$ by considering the exponential change in $\mathrm{N}_{2} \mathrm{O}$ with altitude. The accuracy of retrievals at $190 \mathrm{GHz}$ is about $2-55 \mathrm{ppbv}$ at this altitude range, and the vertical resolution is about $2.5-3 \mathrm{~km}$. The vertical resolution of $\mathrm{ClO}$ measurements at $640 \mathrm{GHz}$ is about $3-$ $3.5 \mathrm{~km}$ over $147-1 \mathrm{hPa}$, and the accuracy of measurements is about $0.2-0.4$ ppbv. The measurements also have a latitudedependent bias of about 0.2-0.4 ppbv, depending on altitude (Santee et al., 1997; Froidevaux et al., 2008; Livesey et al., 2015). The ozonesonde measurements have an uncertainty of 5\%-10\% (Smit et al., 2007).

The OMPS consists of three sensors that measure scattered solar radiances in overlapping spectral ranges and scan the same air masses within $10 \mathrm{~min}$. The nadir measurements are used to retrieve ozone total column and vertical profiles (NPs). The limb profiler (LP) measures profiles with high vertical resolution $(\sim 2-3 \mathrm{~km})$, and the LP retrievals are in good agreement with other satellite measurements, and the differences are mostly within $10 \%$ Kramarova et al., 2014. The OMPS TCO shows $0.6 \%-1.0 \%$ differences with Brewer and Dobson ground-based TCO measurements across the latitudes and is also biased $+2 \%$ when the TCO is above 220 DU Bai et al., 2015, 2016. GOME-2 was flown on the MetOp-A satellite in 2006. The GOME-2 ozone column has a positive bias in the northern high latitudes of about 0.5\%-3.5\% (Loyola et al., 2011). The OMI TCO measurements have an accuracy of about $5 \%$ in the polar regions (Kroon et al., 2008; Kuttippurath et al., 2018). The Brewer spectrometers operate in the UV region, and their ozone observations have an accuracy of about $5 \%$.

The ozone loss is estimated using two different methods and four different datasets to make sure the analyses are robust. The first method used is the widely used profile descent method, wherein the $\mathrm{N}_{2} \mathrm{O}$ data are used for the calculations of air mass descent in the polar vortex. The reference profile of $\mathrm{N}_{2} \mathrm{O}$ was taken from the month of December, and, therefore, the loss calculations are presented from December (May for Antarctic) onwards. The second method used for the calculation of ozone is the passive tracer method, for which a passive odd-oxygen tracer is simulated using a CTM (chemical transport model) and is subtracted from the measured ozone to determine the ozone loss, as the changes in tracer are modulated only by the dynamics (Feng et al., 2005). We have used the SLIMCAT (Single Layer Isentropic Model of Chemistry And Transport) model for the tracer calculations (Chipperfield, 2006) and investigated the Arctic ozone loss under different meteorological conditions including the Arctic winter/spring of 2019/2020 (e.g. Chipperfield et al., 2005; Bognar et al., 2021; Feng et al., 2021; Weber et al., 2021).

\section{Results and discussion}

\subsection{The exceptional meteorology of the Arctic winter/spring of 2019/2020}

Figure 1 shows the times series of stratospheric meteorology in the Arctic winter/spring of 2019/2020 compared to those long-lasting polar vortex years of 1997 and 2011. Time series of the meteorological parameters for all Arctic winters since 1979 are also shown (grey-coloured curves) for comparison. In general, the temperatures are between 210 and $195 \mathrm{~K}$. In 2020 , the temperatures were about $195 \mathrm{~K}$ in December, 190$195 \mathrm{~K}$ in January-March, and $195-205 \mathrm{~K}$ in April. However, the minimum temperature in late winter 2020 is generally lower than $195 \mathrm{~K}$, lasting about $115 \mathrm{~d}$ from December through to early April. The temperatures are lower than those in the 2011 winter, and those in late March and April are the lowest in the observational record. The lower temperatures in late December through to mid-March are key to PSCs, chlorine activation, the maintenance of high values of active chlorine, and ozone loss. Low temperatures are thus a common phenomenon in winters with a large loss of ozone (e.g. 1995, 2000, 2005 and 2011). Therefore, the higher temperatures in early winter and limited chlorine activation were the reasons for relatively smaller ozone loss in 1997, although it was a winter with a strong vortex up to the end of April (Coy et al., 1997; Feng et al., 2007; Kuttippurath et al., 2012). Since minor warmings (mWs) are very common in the Arctic winters, we also examined the occurrence of $\mathrm{mW}$ events by checking the temperature at $90^{\circ}$ (North Pole) and $60^{\circ} \mathrm{N}$ at $10 \mathrm{hPa}$ and zonal winds at $60^{\circ} \mathrm{N}$ at $10 \mathrm{hPa}$. The analyses show a small increase in temperature on 5 February 2020 (i.e. a minor warming) and a corresponding change in zonal winds.

The temperatures were consistently lower than the nitric acid trihydrate (NAT) equilibrium threshold of about $195 \mathrm{~K}$ and therefore, large areas of PSCs are observed from December to mid-February. Even though PSCs may also be composed of liquid particles and not only NAT (e.g. Pitts et al., 2009; Spang et al., 2018), the NAT equilibrium threshold constitutes a good estimate for the occurrence of heterogeneous chemistry (e.g. Drdla and Müller, 2012; Kirner et al., 20151 Grooß and Müller, 2021; von der Gathen et al., 2021). The potential PSC area (APSC) was about $4 \times 10^{6} \mathrm{~km}^{2}$ in December 2020 at $460 \mathrm{~K}$, but it doubled in January through midMarch. The APSC from mid-February to late March is also the largest in the observational record (Fig. 1). The low temperatures (i.e. lower than $188 \mathrm{~K}$ ) also produced a very high amount of ice PSCs at the end of January and early February (up to $4 \times 10^{6} \mathrm{~km}^{2}$ ) when the lowest temperatures in 40 years were recorded in the Arctic. This is the largest ice PSC ever observed in terms of its area, volume, and number of days of appearance (i.e. frequency) in the Arctic, and the area is twice that of the winter of 2011 (also see Deland et al., 2020). The PSC area shrunk to half of its area in late January and February, as the lower-stratospheric temperature increased during 


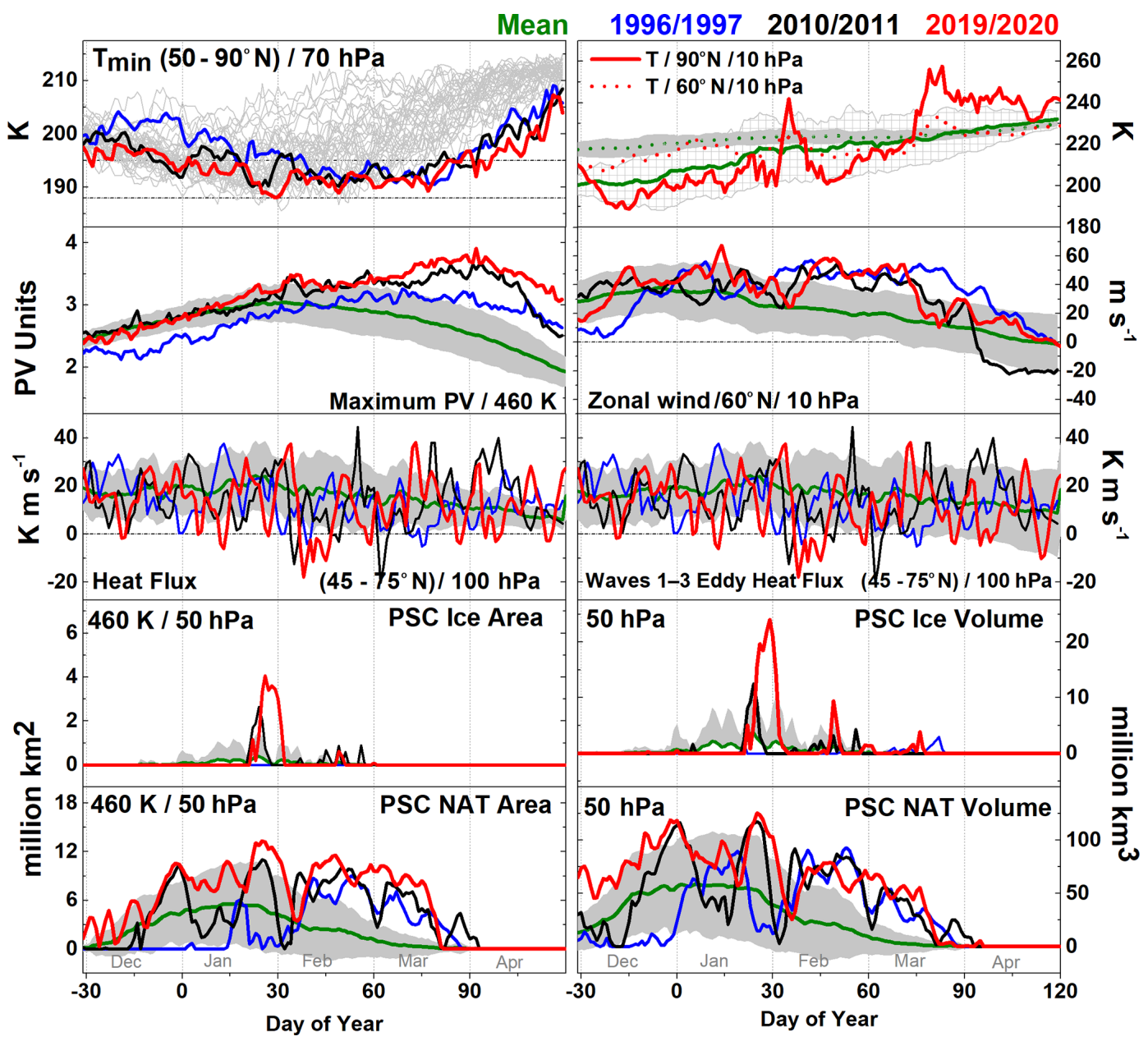

Figure 1. Meteorology of the Arctic winter/spring of 2019/2020. The temperature, zonal winds, potential vorticity (PV), heat flux, wave eddy heat flux, and area and volume of polar stratospheric clouds (PSCs) for the Arctic winter of 2020 as compared to previous Arctic winters. The shaded area shows the standard deviation from the mean.

the period. This was the only occasion that the temperature increased and PSC areas were limited to below $4 \times 10^{6} \mathrm{~km}^{2}$ in the winter of 2020. Note that the PSC area and volume were largest in 2016 not in 2020 (Fig. S1 in the Supplement) (Kirner et al., 2015).

The potential vorticity (PV) at $\sim 17 \mathrm{~km}$ (about $460 \mathrm{~K}$ potential temperature level) shows that the polar vortex was very strong in the lower stratosphere in 2020. The PV values were consistently higher than the previous cold (i.e. 1995, 2000, 200,5 and 2011) and long-lasting (e.g. 1997 and 2011) winters in March and April. This indicates that the winter of 2020 had the strongest vortex in recent history, as demonstrated by the PV time series of different Arctic winters (Fig. 1, second panel, left). However, the zonal winds were strongest in 1997 during the March-April period. The diagnosis with net heat flux and the eddy heat flux associated with planetary waves 1,2 , and 3 demonstrates that the momentum transported from the troposphere to the stratosphere was very weak in 2020 (in the range of -20 to $30 \mathrm{Km} \mathrm{s}^{-1}$ ), and the net heat flux values are zero or negative (e.g. $-10 \mathrm{Km} \mathrm{s}^{-1}$ in February) during most parts of the winter. These results are also in agreement with the eddy heat flux computed for the waves $1-3$, as they also show smaller wave momentum to the stratosphere. In short, the net heat flux and wave 13 heat flux show smaller values in January-April, indicating the reason for the less disturbed long-lasting vortex in 2020. According to Lawrence et al. (2020), apart from the weak tropospheric forcing, the formation of reflective configuration of stratospheric circulation was another factor that aided in the strengthening of the vortex in 2020.

The potential vorticity analyses show a strong and large vortex in early December. The vortex began to grow and occupied the entire polar region (defined by PV vortex edge) by early January, as shown in Fig. 2. The lowest temperatures of the past 40 years were recorded by the end of January and the vortex was exceptionally strong and large (e.g. Wohltmann et al., 2020; Rao and Garfinkel, 2020). The mW distorted and elongated the vortex in early February, but the 
vortex was still strong and continued to be intact until the last week of April 2020. The extraordinary persistence of a strong and undisturbed Arctic vortex in March and April is evident in the PV maps. We also examined the Arctic winters since 1979 in terms of their dynamical activity, as shown in Fig. S1b. The analyses show that, although the average vortex temperature and vortex area at $70 \mathrm{hPa}$ were not very exceptional, the westerly winds $\left(25 \mathrm{~ms}^{-1}\right)$ were strongest and dynamical activity was weakest (with heat flux $17 \mathrm{~K} \mathrm{~ms}^{-1}$ ) in the past 20 years. This further suggests that the winter of 2020 was unique and that wave forcing was very weak during the period.

\subsection{Strong air mass descent and associated ozone distribution}

Figure 3 shows the distribution of ozone, $\mathrm{ClO}, \mathrm{N}_{2} \mathrm{O}, \mathrm{HNO}_{3}$, and the ozone loss estimated for the winter of 2020 using satellite observations. We use the measurements from MLS on the Aura satellite (Livesey et al., 2015). The MLS data have been widely used for the study of polar ozone loss, as the instrument provides measurements of some key ozonerelated chemistry trace gases such as $\mathrm{ClO}, \mathrm{N}_{2} \mathrm{O}$, and $\mathrm{HNO}_{3}$ to delineate the features of chlorine activation, vortex descent, and denitrification, respectively (Manney et al., 2020). The ozone distributions in the vortex show $<1.0 \mathrm{ppmv}$ in December, slightly higher values of about $1.5 \mathrm{ppmv}$ in February and smaller than 1.0 ppmv from mid-March to the end of April at $400 \mathrm{~K}$. The measurements show exceptionally low values of ozone, about $0.5 \mathrm{ppmv}$ or below, during the period of mid-March through to the end of April at 350-450 K. The ozone values show $<2.5$ ppmv from December to midJanuary, $<2$ ppmv in January and February, and $<1.0$ ppmv in March-April at 350-450 K and about 2-4 ppmv above $500 \mathrm{~K}$; suggesting an unusual chemical depletion of ozone in December and late January. The ozone values are about 3-4 ppm above $550 \mathrm{~K}$ throughout the winter; implying little reduction in ozone there. The unusual feature here is the extremely small ozone mixing ratios of $1.0 \mathrm{ppmv}$ in early December and March-April below $450 \mathrm{~K}$ (about $16 \mathrm{~km}$ ). This reveals huge depletion of ozone in the lower stratosphere and therefore, we have quantified the ozone loss for the winter. We estimate the descent rate from the tracer $\mathrm{N}_{2} \mathrm{O}$ inside the polar vortex, then assume the averaged profile descent rate is identical to the dynamical ozone tracer so that the chemical ozone loss can be derived (e.g. Griffin et al., 2019). This is a widely used method for chemical ozone loss estimation (Rex et al., 2002; Jin et al., 2006).

For instance, the MLS measurements show that $\mathrm{N}_{2} \mathrm{O}$ values were $250 \mathrm{ppbv}$ at $400 \mathrm{~K}, 150 \mathrm{ppbv}$ at $500 \mathrm{~K}$ and $50 \mathrm{ppbv}$ at $600 \mathrm{~K}$ in December. The $\mathrm{N}_{2} \mathrm{O}$ observations show strong air mass descent with values down to $100 \mathrm{ppbv}$ at $400 \mathrm{~K}$ and about $25-50$ ppbv above $500 \mathrm{~K}$ in early February. Again, $\mathrm{N}_{2} \mathrm{O}$ values exhibit below 50 ppbv in late March at $400 \mathrm{~K}$. The $\mathrm{N}_{2} \mathrm{O}$ distributions show below $50 \mathrm{ppbv}$ at all altitudes from early February onwards; suggesting substantial dynamic descent in the stratosphere. When a particular altitude is considered, e.g. the $450 \mathrm{~K}$ potential temperature level, the $\mathrm{N}_{2} \mathrm{O}$ values show 160 ppbv in early December, 100 ppbv in early January, 50 ppbv in early February and less than 50 ppbv thereafter. On the other hand, the $\mathrm{N}_{2} \mathrm{O}$ distributions show 50 ppbv in early December and below that value afterwards at $500 \mathrm{~K}$. The severe air mass descent in this winter is further depicted in Fig. S2, where monthly correlations between ozone and $\mathrm{N}_{2} \mathrm{O}$ are presented.

\subsection{Ozone loss and mini-holes in December and January}

There were vortex-wide PSC occurrences in the first week of December, about $2-4 \times 10^{6} \mathrm{~km}^{2}$ in area (APSC) and about $70 \times 10^{6} \mathrm{~km}^{3}$ in volume (VPSC) (see Rex et al., 2005 for the definitions). The APSC and VPSC dropped significantly afterwards and then gradually increased again by midDecember to $10 \times 10^{6} \mathrm{~km}^{2}$ and $120 \times 10^{6} \mathrm{~km}^{3}$, respectively. An unusual increase in activated chlorine is observed during the first week of December in conjunction with the appearance of PSCs. The temperatures began to decrease from $198 \mathrm{~K}$ in mid-December to $187 \mathrm{~K}$ by the end of January, as shown in Fig. 1. The chlorine activation peaked and showed record levels of $\mathrm{ClO}$, about $1.5-2.0 \mathrm{ppbv}$ at $400-600 \mathrm{~K}$, during this period. The chemical ozone loss began in early January with about $0.5 \mathrm{ppmv}$ and increased to $1.5 \mathrm{ppmv}$ by the end of January below $500 \mathrm{~K}$. The loss above that altitude is always lower than $0.5 \mathrm{ppmv}$, which shows that the ozone loss is restricted to the altitudes below $21 \mathrm{~km}$ (i.e. $550 \mathrm{~K}$ ).

In general, the ozone loss starts in December in the middle stratosphere and then gradually progresses towards the lower stratosphere by January. The loss would be below $0.5 \mathrm{ppmv}$ in December and about 0.5-1.0 ppmv in January in the lower stratosphere in cold Arctic winters. However, in the Arctic winter of 2020, the $\mathrm{ClO}$ and ozone loss show unusually high values of about 1.5-2.0 ppbv and 1.5-2.0 ppmv, respectively. Since ozone loss of this scale requires sunlight and high levels of $\mathrm{ClO}$, and one would not expect substantial amounts of sunlight in the early winter Arctic vortex, the appearance of huge amounts of $\mathrm{ClO}$ during this period is surprising. The only possibility to have such high-levels of chlorine activation is the displacement of vortex to sunlit latitudes. The analyses of vortex position in early December and late January (Fig. 2) reveal that the vortex was at $55-60^{\circ} \mathrm{N}$. Therefore, a strong polar vortex, very low temperatures, large volumes of PSCs and shift of vortex to the sun light part of midlatitudes caused the unprecedented chlorine activation and ozone loss in the first week of December and late January. This is similar as that of the Arctic winter of 2002/2003 (e.g. Goutail et al., 2005; Kuttippurath et al., 2011).

In addition to the ozone loss inside the vortex, there is another interesting phenomenon in December and January. The analyses of TCO show that there were Arctic ozone mini- 

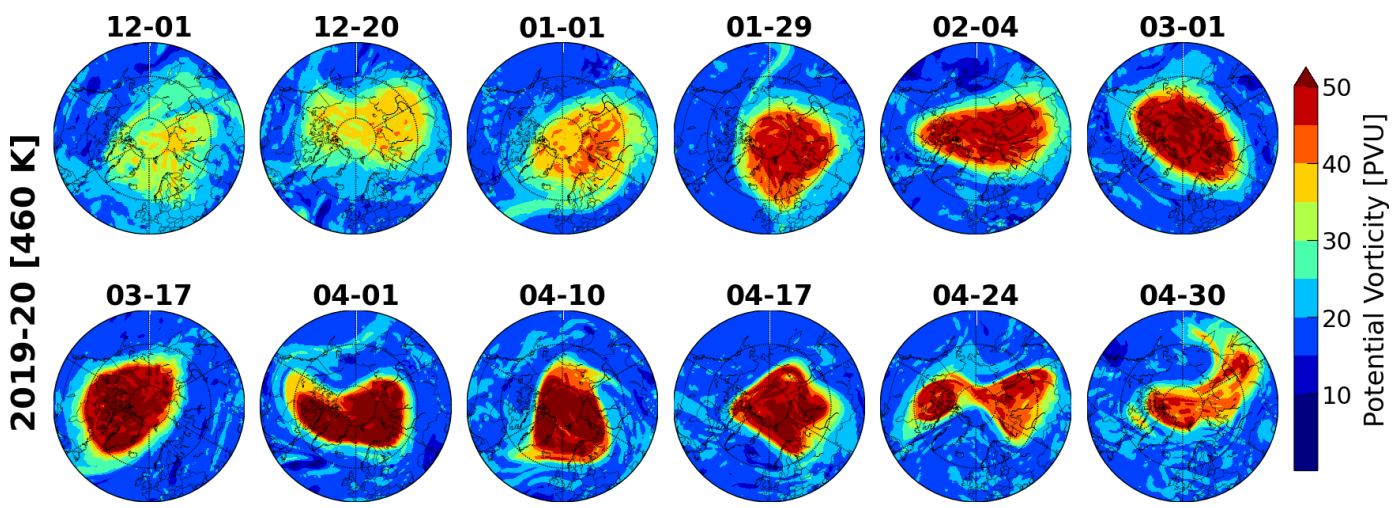

Figure 2. Polar vortex evolution in the Arctic winter/spring of 2019/2020. The evolution of polar vortex in the Arctic winter of 2020. The vortex situation in the lower-stratospheric altitude of about $460 \mathrm{~K}(\sim 17 \mathrm{~km})$ is illustrated. The vortex edge is calculated with respect to the Nash et al. (1996) criterion at each altitude.

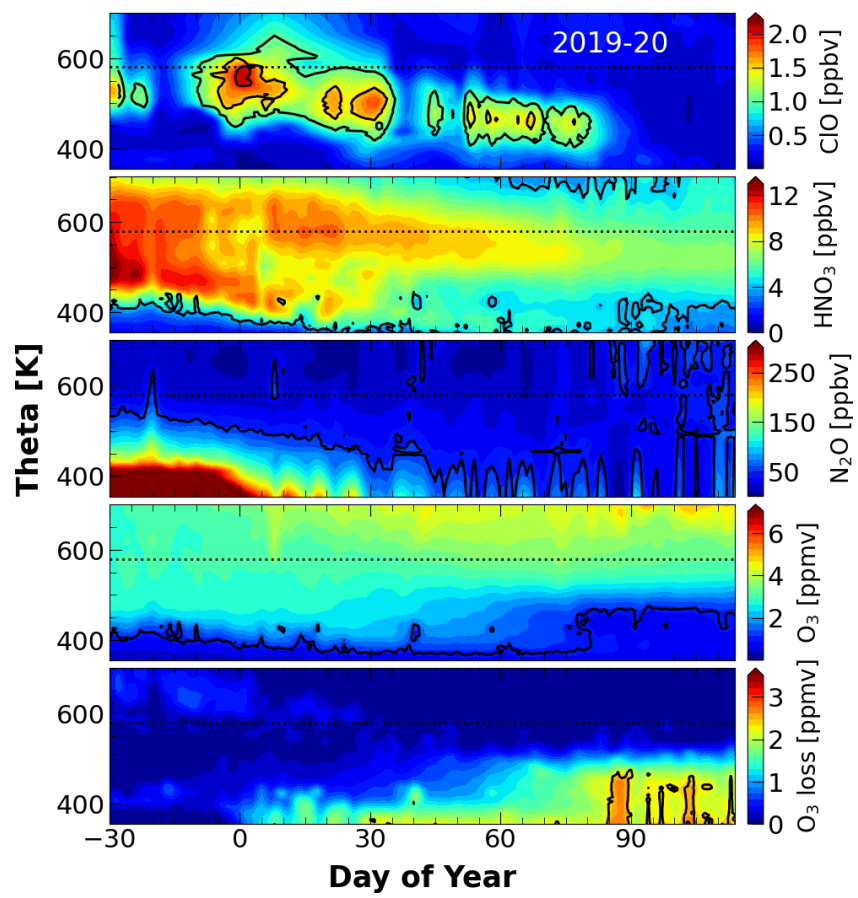

Figure 3. Ozone loss in the Arctic polar vortex in 2020. The distribution of $\mathrm{ClO}, \mathrm{HNO}_{3}, \mathrm{~N}_{2} \mathrm{O}$ and ozone (top to bottom) as measured by the Microwave Limb Sounder (MLS) for the Arctic winter of 2020. The bottom panel shows the ozone loss estimated using the MLS ozone by applying the tracer descent method (see Methods and Supplement). The vortex edge is computed in accordance with Nash et al. (1996) criterion. The vortex-sampled data are then averaged over each day and are shown.

holes (e.g. Stenke and Grewe, 2003; Rieder and Polvani, 2013 ) of about $300-700 \mathrm{~km}^{2}$ size in the first week of December (1-6 December 2019) and on 26 January 2020 (Fig. 4). The lowest TCO measured of the winter was also at the latter date. A detailed analysis with $\mathrm{TCO}, \mathrm{PV}$, temperature and $\mathrm{ClO}$ reveals that those ozone mini-holes were dynamically driven, as there was rapid air mass transport to the southern Arctic in early December and late January. These ozone mini-hole occurrences due to rapid changes in weather patterns and the total column ozone returns to the amount of normal levels of ozone in a few days.

Ozone mini-holes are a dynamically driven sporadic decrease in TCO observed mostly in the midlatitudes of both hemispheres due to rearrangement of the ozone column associated with tropospheric weather systems (Reed, 1950). The mini-holes are called so, as the TCO is less than $220 \mathrm{DU}$ in those areas, and is one of the criteria defining the Antarctic ozone hole, although they differ in the nature of formation and spatial extent. These transient spatial and temporal events were identified first by Dobson and Harrison (1926) much before the identification of chemical ozone loss and were referred to as mini-holes by Newman et al. (1988) and McKenna et al. (1989). The plunge in TCO results when, the horizontally advected ozone poor tropospheric air mass interacts with the vertical air column motions in the anticyclonic ridging regions of the upper troposphere in the polar regions. As a consequence of this divergence, mixing or both may result in the appearance of mini-holes (e.g. Peters et al., 1995; James et al., 1997; Canziani et al., 2002). Since its identification, the criteria for the definition of mini-holes differed based on the thresholds of TCO amounts and spatial coverage in different geographical locations (Millán and Manney, 2017). In our study the threshold is taken to be $220 \mathrm{DU}$ (see Bojkov and Balis, 2001). Many studies have also analysed the mini-hole formations in the Northern Hemisphere (e.g. James, 1998; Krzyścin, 2002; Stenke and Grewe, 2003; Feng, 2006). Here, we analyse the ozone mini-holes that appeared in the polar region of the winter of 2020 and their dynamical origin.

We used the HYSPLIT trajectory model to find the air mass transport at three different altitudes (17, 18 and $19 \mathrm{~km})$ in the lower stratosphere, where the mini-holes are found (Fig. 4, right panels). The air mass exported from mid- and 




Figure 4. The Arctic ozone mini-holes in December 2019 and January 2020. The total ozone observations by Ozone Monitoring Instrument (OMI) on 3 December 2019 and 26 January 2020. The potential vorticity (PV) maps for the corresponding dates are shown on the right. The air mass trajectories computed using the HYSPLIT model at 17, 18 and $19 \mathrm{~km}$ are also illustrated in the PV maps. The ozonesonde measurements in December and January at Alert $\left(62.34^{\circ} \mathrm{N}, 82.49^{\circ} \mathrm{W}\right)$ and Eureka $\left(79.99^{\circ} \mathrm{N}, 85.90^{\circ} \mathrm{W}\right)$ are illustrated in the bottom panel and are also shown in the maps as red and magenta stars, respectively.

low latitudes has very low PV values, low temperature and high ClO. It suggests that the ozone transported from midlatitudes triggered the ozone "holes" (ozone values $<220 \mathrm{DU}$ ). To further examine the low ozone values outside the vortex, we selected two ozonesonde measurements in the region (Alert: $62.34^{\circ} \mathrm{N}, 82.49^{\circ} \mathrm{W}$ and Eureka: $79.99^{\circ} \mathrm{N}, 85.90^{\circ} \mathrm{W}$ ), which are shown in bottom panels of Fig. 4 for selected dates in December and January. These measurements show significant reduction in ozone (Coy et al., 1997; Feng et al., 2007; Hurwitz et al., 2011) between 12 and $18 \mathrm{~km}$; confirming the findings from the satellite total column measurements. Note that similar ozone mini-hole occurrences with comparable
TCO, very low temperatures with huge VPSCs and high $\mathrm{ClO}$ in the mini-holes were also reported in some previous Arctic winters (e.g. Weber et al., 2002; Feng, 2006).

It should be mentioned that there was already large chemical loss of ozone inside the Arctic vortex in early December and late January owing to the conventional polar ozone loss chemistry (as shown in Fig. 3). However, the ozone miniholes that appeared outside the vortex were primarily caused by dynamics. We cross-checked TCO from OMI (Bais et al., 2018), OMPS (Flynn et al., 2014), GOME-2 (Loyola et al., 2011) and MERRA-2 (Gelaro et al., 2017), and found that the ozone mini-holes were present in all these TCO datasets. 


\subsection{Prolonged chlorine activation and chemical ozone loss}

When the Arctic winters are very cold, chlorine activation occurs in the Arctic lower stratosphere at 400-500 K in January and February. In 2011, the chlorine activation was observed up to the end of February and was intermittent with a peak value of about $1.6 \mathrm{ppbv}$, and was mostly at $400-500 \mathrm{~K}$ (e.g. Manney et al., 2011; Kuttippurath et al., 2012; Livesey et al., 2015; Griffin et al., 2019). Conversely, in the Arctic winter of 2020, there was continuous and sustained chlorine activation from December to early April, except during the $\mathrm{mW}$ periods of mid-December and early February. The $\mathrm{ClO}$ values are also $0.5 \mathrm{ppbv}$ larger than those observed in the winter of 2011. Feng et al. (2021) also stated that the chlorine activation in 2020 lasted longer than that in 2010/2011. Therefore, strong chlorine activation was observed in March-April with $\mathrm{ClO}$ values of about $1.0-1.6 \mathrm{ppbv}$ at $400-550 \mathrm{~K}$ and the peak $\mathrm{ClO}$ value is about $2.1 \mathrm{ppbv}$.

The minor warming (Fig. 1) caused a break in chlorine activation (Fig. 3 for $\mathrm{ClO}$ ) in early March. Nevertheless, the temperature decreased shortly thereafter, which produced continued chlorine activation until early April at 400-550 K. The ozone loss deepened in March and peaked by the end of March and showed a maximum of about 1.5-3.4 ppmv at a broader altitude range of up to $500 \mathrm{~K}$. The ozone loss above that altitude (i.e. $550 \mathrm{~K}$ ) was about $0.5-1 \mathrm{ppmv}$, which is still larger than that of any other Arctic winter. In fact, the loss of $1.0 \mathrm{ppmv}$ is the peak loss observed in normal or moderately cold winters of the Arctic (e.g. Kuttippurath et al., 2013); suggesting the severity of ozone loss even at the higher altitudes in this winter. The maximum loss in 2020 was recorded at the end of March to the end of April: about 2.0-3.4 ppmv at $400-500 \mathrm{~K}$ and about $0.5-1.5 \mathrm{ppmv}$ at $500-600 \mathrm{~K}$. Furthermore, when compared to the early winter values, the late winter low $\mathrm{HNO}_{3}$ values suggest very severe denitrification: about $2-4$ ppbv in the same period at 350-450 K (e.g. Manney et al., 2020). The $\mathrm{HNO}_{3}$ values in the lower stratosphere in March-April are about $60 \%-80 \%$ lower than those of December-February at the same altitude levels (Pommereau et al., 2018; Lindenmaier et al., 2012). The gravest denitrification was in December, with values of about $0-2$ ppbv below $400 \mathrm{~K}$ and $4-6 \mathrm{ppbv}$ at $400-450 \mathrm{~K}$. Therefore, high chlorine activation and strong denitrification (as deduced from the $\mathrm{HNO}_{3}$ analyses shown in Fig. 3) provided the basis for an unprecedented situation for a large ozone loss of about 2-3.4 ppmv in the lower stratosphere in March-April.

Since the ozone loss in 2020 is exceptionally larger, we have employed another set of measurements to estimate ozone loss to reconfirm that the derived results are robust. The loss estimated from OMPS measurements together with other analyses is shown in Fig. 5 (left). The maximum ozone loss profile extracted from the OMPS data shows very good agreement with that from the MLS measurements for the Arctic winter of 2020. The peak ozone loss values show about $2-2.8 \mathrm{ppmv}$ in the lower stratosphere below $550 \mathrm{~K}$. Since the maximum ozone loss profiles are averaged for a few days, the loss values are slightly lower than those from MLS. The lower stratosphere shows similar ozone loss values, but the loss above $500 \mathrm{~K}$ shows slightly smaller values $(0.1-0.5 \mathrm{ppmv})$ due to the low bias of OMPS measurements at these altitudes as compared to the MLS measurements (Kramarova et al., 2014). The comparison with OMPS confirms that the method adopted for ozone loss is robust. Our estimates are in good agreement with those of Manney et al. (2020), Weber et al. (2021), and Wohltmann et al. (2020), who also derive a loss of about 2.1-2.8 ppmv below $450 \mathrm{~K}$ from the MLS measurements.

\subsection{The Arctic ozone loss in the context of other Arctic winters}

Arctic winters are normally warmer that those in the Antarctic, and occurrences of PSCs are sparse and infrequent. Therefore, high chlorine activation and significant ozone loss are limited to winters with very low temperatures in December-February (Tilmes et al., 2008; Goutail et al., 2005; WMO, 2018; Newman et al., 2009; Kuttippurath et al., 2012). The ozone loss observed in warm winters (e.g. 2006 and 2009) is about $0.5-0.7 \mathrm{ppmv}$, that in moderately cold winters (e.g. 2008 and 2010) is about 1.0-1.2 ppmv, and that in very cold winters (e.g. 2005) is 1.4-1.6 ppmv (e.g. WMO, 2018). However, the ozone loss in the winter of 2011 was about $1.0 \mathrm{ppmv}$ (or 30-40 DU) larger than that of other Arctic winters (about 2.1-2.3 ppmv or 100-100 DU). This ozone loss was similar to the loss found in warmer, more perturbed Antarctic winters (e.g. 1988 and 2002) (Manney et al., 2011; Kuttippurath et al., 2012; Feng et al., 2011; Pommereau et al., 2018). We applied the same loss estimation method to the measurements for the Arctic winter of 2011 to compare with that of the Arctic winter of 2020. This would also test the veracity of the loss estimation procedure and the results are shown in Fig. 5.

The peak ozone loss in the Arctic winter of 2011 is about $2.1 \mathrm{ppmv}$, which is in very good agreement with all other available analyses for that winter (WMO, 2014, 2018; Griffin et al., 2018; Livesey et al., 2015). However, the ozone loss in the Arctic winter of 2020 is about 0.7 ppmv higher than that in 2011: about 2.8 ppmv. The difference in ozone loss between the winters is negligible above $480 \mathrm{~K}$. Therefore, it is evident that the ozone loss in the Arctic winter of 2020 is the largest on record and is significantly higher than that of any previous Arctic winter (Grooß and Müller, 2021).

Furthermore, we applied another loss estimation method to test the robustness of the extreme ozone loss values; the passive method that uses a passive tracer (i.e. no chemistry) simulation. We have used the well-known and widely used TOMCAT/SLIMCAT model simulations for the tracer calculations (Chipperfield, 2006; Dhomse et al., 2019). The ozone loss computed with the passive method shows the peak value 


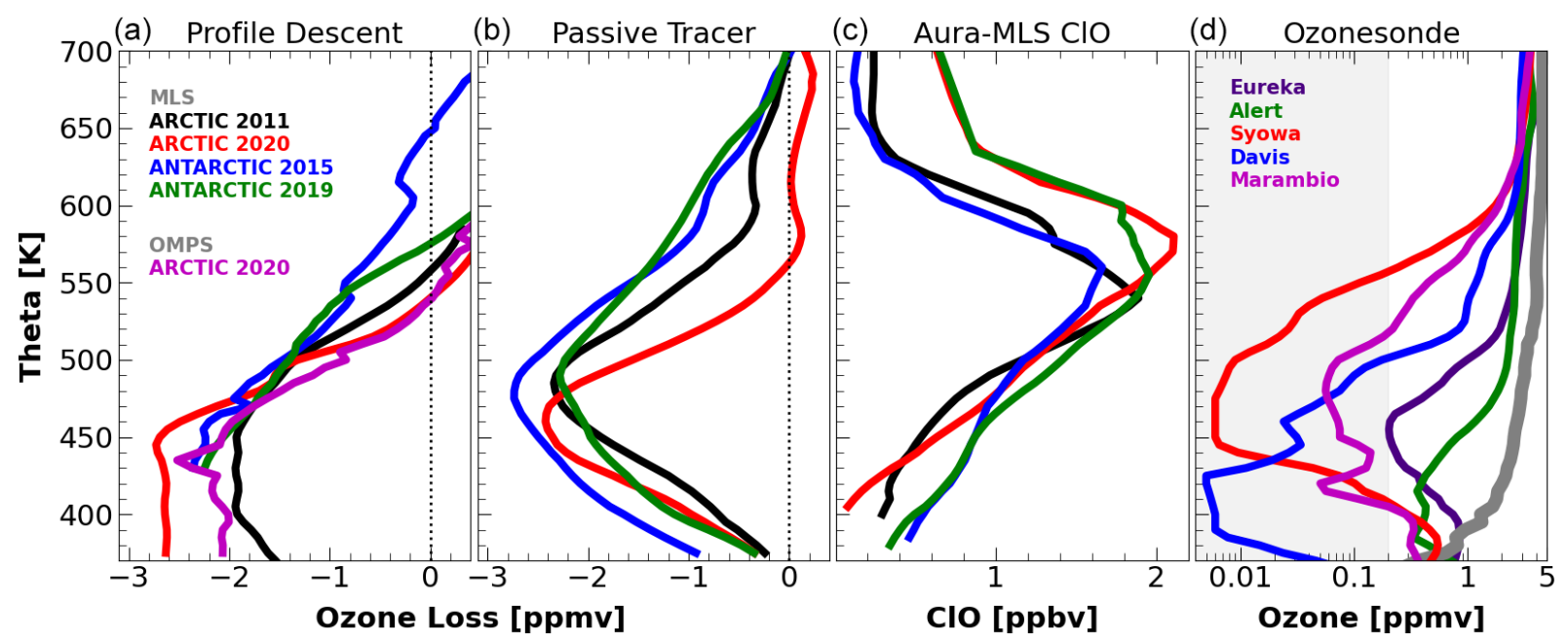

Figure 5. The Arctic and Antarctic ozone loss saturation and chlorine activation. (a) The ozone loss estimated using the Microwave Limb Sounder (MLS) measurements by applying the vortex descent method for the Arctic winter of 2019-2020 compared to the Arctic winter of 2011 and the Antarctic winters of 2015 and 2019. The ozone loss estimated with Ozone Mapping and Profiler Suite (OMPS) measurements is also shown. (b) The ozone loss estimated using the passive tracer method for the Arctic winter of 2020 and the Antarctic winters of 2015 and 2019. (c) The activated profiles ClO measured by MLS for the Arctic winters of 2011 and 2020 and the Antarctic winters of 2015 and 2019. The profiles are selected for the days with peak $\mathrm{ClO}$ values and are averaged for $3 \mathrm{~d}$. (d) Ozonesonde measurements from selected Antarctic and Arctic stations. The Antarctic ozonesonde measurements (Davis, Marambio, and Syowa) from past winters and the Arctic measurements (Alert and Eureka) from the Arctic winter of 2020. The grey colour represents an ozone profile without ozone depletion in the Arctic and Antarctic. The grey-shaded region represents the ozone loss saturation threshold. The dates of ozonesonde measurements are 8 April 2020 (Alert) and 10 April 2020 (Eureka).

of about 2.3-2.5 ppmv at about $450 \mathrm{~K}$ in the Arctic winter of 2020 (Fig. 5, second panel from the left). This ozone loss is slightly higher than that of the Arctic winter of 2011: about 0.2 ppmv. It is also observed that the ozone loss in 2020 is higher than that of 2011 below $475 \mathrm{~K}$, but the loss estimated in the 2011 winter exceeds about $0.3-0.5$ ppmv above $475 \mathrm{~K}$ up to $700 \mathrm{~K}$ (e.g. Manney et al., 2020; Wohltmann et al., 2020). However, these ozone loss estimates are lower by about $0.5-0.7 \mathrm{ppmv}$ than those estimated with the descent method, depending on altitude. The analysis with ozone and $\mathrm{N}_{2} \mathrm{O}$ from the model indicates that modelled ozone is higher (by about 1-1.5 ppmv) than the measurements at these altitudes, which could be due to the slower dynamical descent in the model.

It is clear that the ozone loss in 2020 is the largest among Arctic winters so far. Therefore, we also examined the evolution of chlorine activation in terms of the amount of $\mathrm{ClO}$ in each Arctic winter, as the total chlorine is decreasing in the stratosphere due to the effect of the Montreal Protocol (e.g. Strahan and Douglass, 2018; WMO, 2018; Dhomse et al., 2019), and we expect a corresponding response in ozone loss in the polar winters. Stratospheric halogen levels (effective equivalent stratospheric chlorine, EESC) in the Arctic in 2020 are more than $10 \%$ below the maximum levels in 2000 (Grooß and Müller, 2021). Figure 6 shows the MLS ClO observations, the December-February and December-March potential PSC areas, and EESC in each winter since 2005.
The analyses show that the chlorine activation was very severe and continuous for about 4 months in 2020. However, the highest $\mathrm{ClO}$ and largest APSC values were observed in winter 2016. Many cold winters showed $\mathrm{ClO}$ values around $1.8-2.0 \mathrm{ppbv}$ as found in 2020, but the sustained chlorine activation that was observed in 2020 was unique. Although the high $\mathrm{ClO}$ values in March were also observed in 2011, the chlorine activation was not as severe as in 2020 in early winter (December-January). The record-breaking spatial extent of ice PSCs in the winter of 2020 might have also contributed to the exceptional chlorine levels. On the other hand, the unprecedented chlorine activation observed in 2016 was more episodic, such as in mid-December, mid-January to early February, and late February. Therefore, the continuous and severe chlorine activation from December through March was the key for the record-breaking ozone loss in 2020. Figure $6 \mathrm{~b}$ and $\mathrm{c}$ further illustrate that the peak $\mathrm{ClO}$ profiles or the time series of average $\mathrm{ClO}$ for the entire winter will not reveal the depth of chlorine activation. We also looked at the changes in EESC during the period (2005-2020), and there has been a continuous decline in EESC during the period (Fig. 6, top panel). The predicted rate of change of EESC during the period is about 246.16 ppt per year (e.g. WMO, 2018); suggesting a reduction in stratospheric halogen loading in 2020 compared to the peak loading by about $10 \%$ (e.g. Grooß and Müller, 2021). 


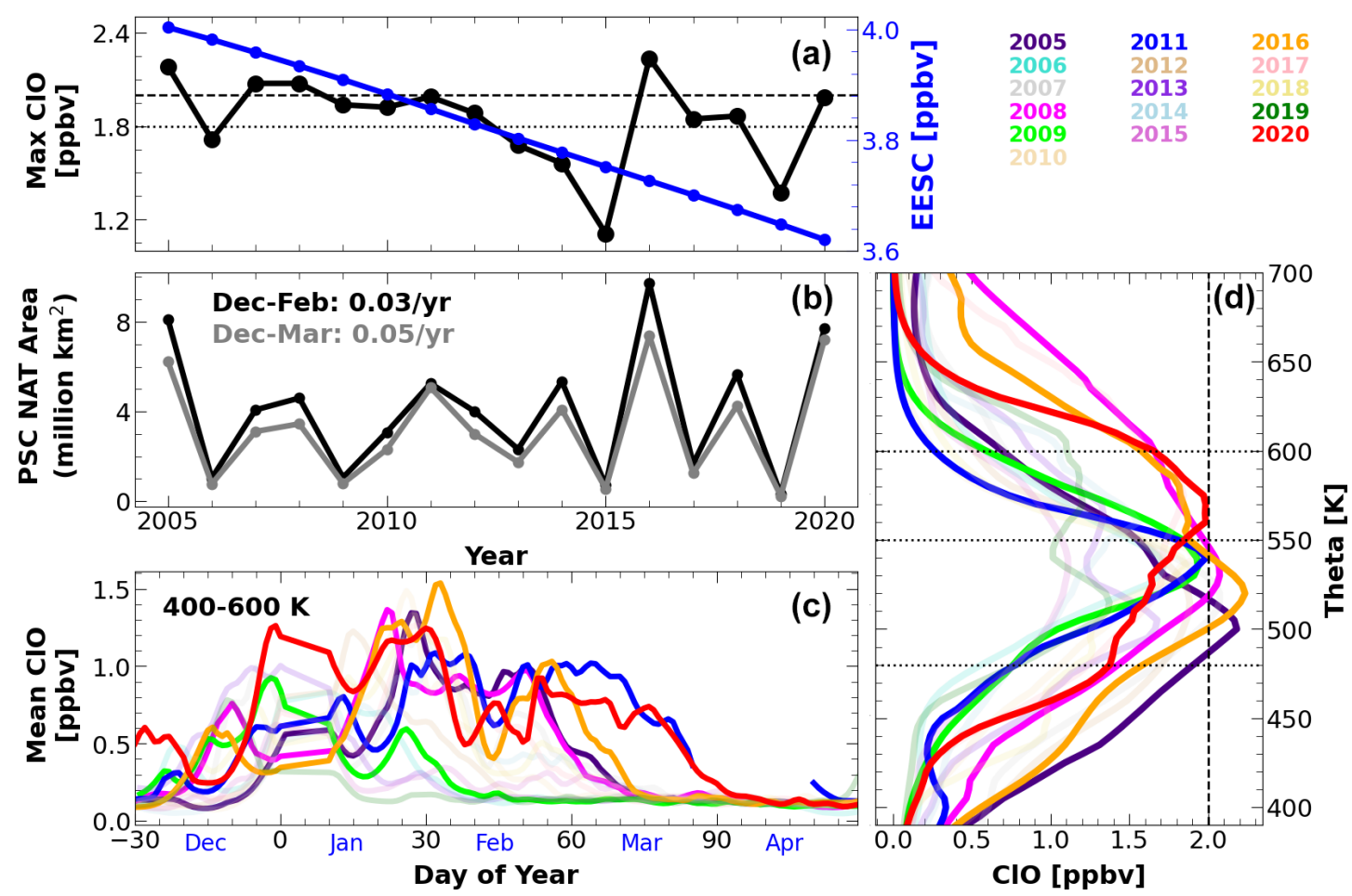

Figure 6. PSC and chlorine activation in the Arctic winters of 2005-2020. (a) The temporal evolution of ClO in the Arctic winters as measured by the Microwave Limb Sounder (MLS) inside the vortex and effective equivalent stratospheric chlorine (EESC). (b) The area of PSC averaged for the period December-February and December-March (grey) for the winter since 2005. (c) The maximum ClO measured inside the vortex in each winter from 2005 to 2020. (d) The maximum ClO profiles measured inside the vortex for Arctic winters since 2005. The high chlorine activation with high $\mathrm{ClO}$ values is shown in bright colours and others are faded in (a) and (c). Since the chlorine activation timing is different in different winters, the peak $\mathrm{ClO}$ observed between December and April/March are shown.

\subsection{The Arctic ozone loss and the Antarctic ozone loss}

The peak ozone loss in the Antarctic happens at around $500 \mathrm{~K}$, and the loss is severe from 400 to $600 \mathrm{~K}$ for 5 months continuously from August to November (Tilmes et al., 2006; Huck et al., 2005; Sonkaew et al., 2013; Kuttippurath et al., 2015; Kirner et al., 2015). In contrast, the cold Arctic winters are normally shorter and maximum ozone loss occurs at around $425-475 \mathrm{~K}$ for a period of about 2 months from midJanuary to mid-March (e.g. Kuttippurath et al., 2010; Manney et al., 2003). The ozone loss in the Arctic is limited to the altitudes below $500 \mathrm{~K}$. The ozone loss in the Arctic winter of 2020 was very high, and, therefore, we compare the Arctic ozone loss in 2020 with that in the Antarctic winters of 2015 and 2019. The Antarctic winter of 2015 was one of the coldest and 2019 was one of the warmest, and, therefore, the assessment would give an upper and lower bound of ozone loss estimate for the Arctic winter of 2020.

The peak ozone loss estimated using the vortex descent method is about $2.8 \mathrm{ppmv}$ at $480 \mathrm{~K}$ in the Antarctic winter of 2015 and about 2.3 ppmv at $490 \mathrm{~K}$ in 2019 (Fig. 5). The ozone loss in the Antarctic winter of 2015 shows consistently higher values (about $0.1-0.5 \mathrm{ppmv}$ ) than that of 2019 up to $550 \mathrm{~K}$, and the loss is similar above that altitude in both win- ters. The ozone loss is about $1.0 \mathrm{ppmv}$ at $370 \mathrm{~K}, 2.6 \mathrm{ppmv}$ at $460 \mathrm{~K}, 1.5 \mathrm{ppmv}$ at $550 \mathrm{~K}$, and $0.5 \mathrm{ppmv}$ at $650 \mathrm{~K}$, and it terminates at $700 \mathrm{~K}$ in the Antarctic winter of 2015. In the Arctic winter of 2020, the ozone loss shows about $0.3 \mathrm{ppmv}$ at $370 \mathrm{~K}, 2.0 \mathrm{ppmv}$ at 430 , and $480 \mathrm{~K}, 1.5 \mathrm{ppmv}$ at $550 \mathrm{~K}$, and loss terminates above that altitude. The peak ozone loss is about $2.3 \mathrm{ppmv}$ at $460-470 \mathrm{~K}$. On the other hand, the loss in the Antarctic winters above $470 \mathrm{~K}$ is very large and reaches up to $700 \mathrm{~K}$. The peak ozone loss in the Arctic winter of 2020 is about 2.8 (2.3) ppmv and is at $460-470 \mathrm{~K}$. This is also the main difference between the Arctic and Antarctic ozone loss, as the broader and larger ozone loss occurs above the $470 \mathrm{~K}$ in the Antarctic. The difference is almost 1.0 ppmv above the peak ozone loss altitude. Therefore, the ozone loss in the Arctic winter of 2020 is either equal or larger than that of the Antarctic winter of 2019 below $470 \mathrm{~K}$, but the loss is smaller than that of the Antarctic winters above $525 \mathrm{~K}$.

We have also applied the passive method to further examine the estimated loss in the Arctic and Antarctic winters (Fig. 5, second panel from the left). The ozone loss estimated with the passive method exhibits smaller values in the lower stratosphere in comparison with that derived from the descent method. The loss is about $0.2 \mathrm{ppmv}$ at $350 \mathrm{~K}, 1.6 \mathrm{ppmv}$ 
at $400 \mathrm{~K}$, and $2.3 \mathrm{ppmv}$ at $450 \mathrm{~K}$ in the Arctic winter of 2020 . The peak loss is recorded at $450-460 \mathrm{~K}$, and the loss decreases with altitude: about $1.5 \mathrm{ppmv}$ at $500 \mathrm{~K}$ and $0.1 \mathrm{ppmv}$ at $530 \mathrm{~K}$. In the Antarctic winter of 2019, the ozone loss shows similar values as that of the Arctic winter of 2020 at $370-420 \mathrm{~K}$ but slightly smaller than that of the Arctic winter at $420-470 \mathrm{~K}$. The maximum ozone loss in Antarctic winter 2019 is estimated to be about $2.3 \mathrm{ppmv}$ at $470 \mathrm{~K}$ and about $0.5-1.5$ ppmv above that altitude, which is higher than that of the Arctic winter of 2020. Furthermore, the Arctic ozone loss halts at about $550 \mathrm{~K}$, whereas the Antarctic ozone loss at this altitude is as high as $1.5 \mathrm{ppmv}$. In the Antarctic winter of 2015 , the ozone loss is about $1.0 \mathrm{ppmv}$ at $370 \mathrm{~K}$ and $2.0 \mathrm{ppmv}$ at $400 \mathrm{~K}$, and the peak loss is about $2.8 \mathrm{ppmv}$ at $475 \mathrm{~K}$. The loss gradually decreases with altitude, such as $2.1 \mathrm{ppmv}$ at $500 \mathrm{~K}, 1.5 \mathrm{ppmv}$ at $550 \mathrm{~K}, 1.0 \mathrm{ppmv}$ at $600 \mathrm{~K}$, and $0.5 \mathrm{ppmv}$ at $650 \mathrm{~K}$. The diagnosed ozone loss in the Antarctic winter of 2015 is thus higher by about $0.5-1.5$ ppmv than that of the Antarctic winter of 2019 and the Arctic winter of 2020, depending on the altitude. The assessment further provides strong evidence that the peak ozone loss in the Arctic winter of 2020 is similar to that of the warm winters of the Antarctic (e.g. 2019). The loss estimation method can have uncertainty in the range of $3 \%-5 \%$, depending on the winter months. For instance, the monthly mean ozone loss and its standard deviation for each winter month of 2020 are shown in Fig. S3. A complete error analysis of the passive method to estimate ozone loss has already been presented in Kuttippurath et al. (2010).

\subsection{The first appearance of ozone loss saturation in the Arctic}

Ozone loss saturation (i.e. $\mathrm{O}_{3}$ values less than $0.1 \mathrm{ppmv}$ ) is a common feature of Antarctic winters since 1987 (Jiang et al., 1996; Solomon et al., 2005; Kuttippurath et al., 2018). However, as compared to the Antarctic, the Arctic winters are relatively short (December-March), stratospheric temperatures are about $10 \mathrm{~K}$ higher, occurrence of PSCs are infrequent, denitrification is modest, and, thus, ozone loss is generally more moderate. Therefore, the Arctic never encountered ozone loss saturation (i.e. the near-complete (about $90 \%-95 \%$ ) loss of ozone at some altitudes in the lower stratosphere between 400 and $550 \mathrm{~K}$ ) there before. Apart from these conditions, the vortex-averaged ozone loss normally happens only up to $25 \%-30 \%$ in the Arctic winters as analysed from ground-based spectrometer observations, and, henceforth, a loss saturation was unexpected for the Arctic conditions. Figure 5 (right) shows the ozone profile measurements by ozonesondes at two Arctic stations Alert $\left(82.50^{\circ} \mathrm{N}, 62.33^{\circ} \mathrm{W}\right)$ and Eureka $\left(80.05^{\circ} \mathrm{N}, 86.42^{\circ} \mathrm{W}\right)$ - on selected days. The ozone profiles measured at selected Antarctic stations are also shown for comparison. In general, the ozone loss saturation in Antarctica occurs at the altitude between 400 and $500 \mathrm{~K}$ (e.g. Davis: $68.6^{\circ} \mathrm{S}, 78.0^{\circ} \mathrm{E}$ and Marambio: $64^{\circ} \mathrm{S}, 56^{\circ} \mathrm{W}$ ), and the altitude range would go up to $550 \mathrm{~K}$ for the stations that are always inside the vortex, as shown for Syowa. Note that the ozone loss saturation is taken as $0.2 \mathrm{ppmv}$ and the ozone detection limit of sondes is 10 ppbv (Kuttippurath et al., 2018; Solomon et al., 2005; Vömel and Diaz, 2010). The ozone loss observed at Davis and Marambio is always smaller than that at Neumayer, the South Pole, and Syowa. Therefore, ozone loss saturation is also different at different stations in the Antarctic. Here, the ozonesonde measurements at Alert (on 8 April 2020) show loss saturation at the altitudes $420-475 \mathrm{~K}$ (e.g. Wilka et al., 2021). The measurements at Eureka (on 10 April 2020) show loss saturation with about $99 \%$ ozone loss at altitudes between 420 and $460 \mathrm{~K}$ (see also Bognar et al., 2021). The time series of ozone measurements, as analysed from the available measurements, show that the ozone loss saturation occurred at these stations in early April (Fig. S4). The vertical shading in Fig. 5 for 0.2 ppmv shows the ozone loss saturation criterion with respect to the ozone volume mixing ratios and the ozonesonde measurements have an uncertainty of $5 \%-$ $10 \%$ (Smit et al., 2007). Yet, the ozone measurements at Alert and Eureka are in the saturation limit and, thus, provide the first evidence for the occurrence of ozone loss saturation in the Arctic. The loss saturation suggests that the Arctic polar stratospheric has entered a new era of change. Our analyses are consistent with the analyses of Wohltmann et al. (2020), who report about $90 \%-93 \%$ loss of ozone in the $450-475 \mathrm{~K}$ range in 2020 , and with those of Grooß and Müller (2021), who find a lowest simulated ozone mixing ratio of about $40 \mathrm{ppbv}$ in 2020 .

\subsection{Days with ozone values below a threshold of $220 \mathrm{DU}$}

Since the Antarctic ozone hole is defined with respect to TCO measurements (i.e. below $220 \mathrm{DU}$ ), we analysed TCO measurements for the Arctic in 2020, which are shown in Fig. 7. The figure shows the lowest TCO measurements made in the Arctic polar region in the winter of 2020 by three different satellite instruments: OMI, OMPS, and GOME. As shown (Fig. 7), the OMI measurements show TCO below $300 \mathrm{DU}$ for almost all winter months inside the vortex, as defined by Nash et al. (1996). The measurements show around 230 DU in early December, about 260 DU in January, about 218260 DU in February, around 220 DU in March, and around 240 DU in April. There are ozone values lower than or equal to 220 DU in early (1-5) December, late (25-26) January, some days $(5,12$ and 17-22) in March, and a few days in early (6-7) April. The occurrences of these low ozone values in December and January are associated with ozone miniholes triggered by dynamics. However, the appearances of extremely low TOC values, below 220 DU, in March and April are driven by chemistry, and this is our topic of discussion. The very low ozone measured by OMI corresponding to the dates is also shown in the ozone maps in the top panel, and the exact dates of extremely low ozone occur- 

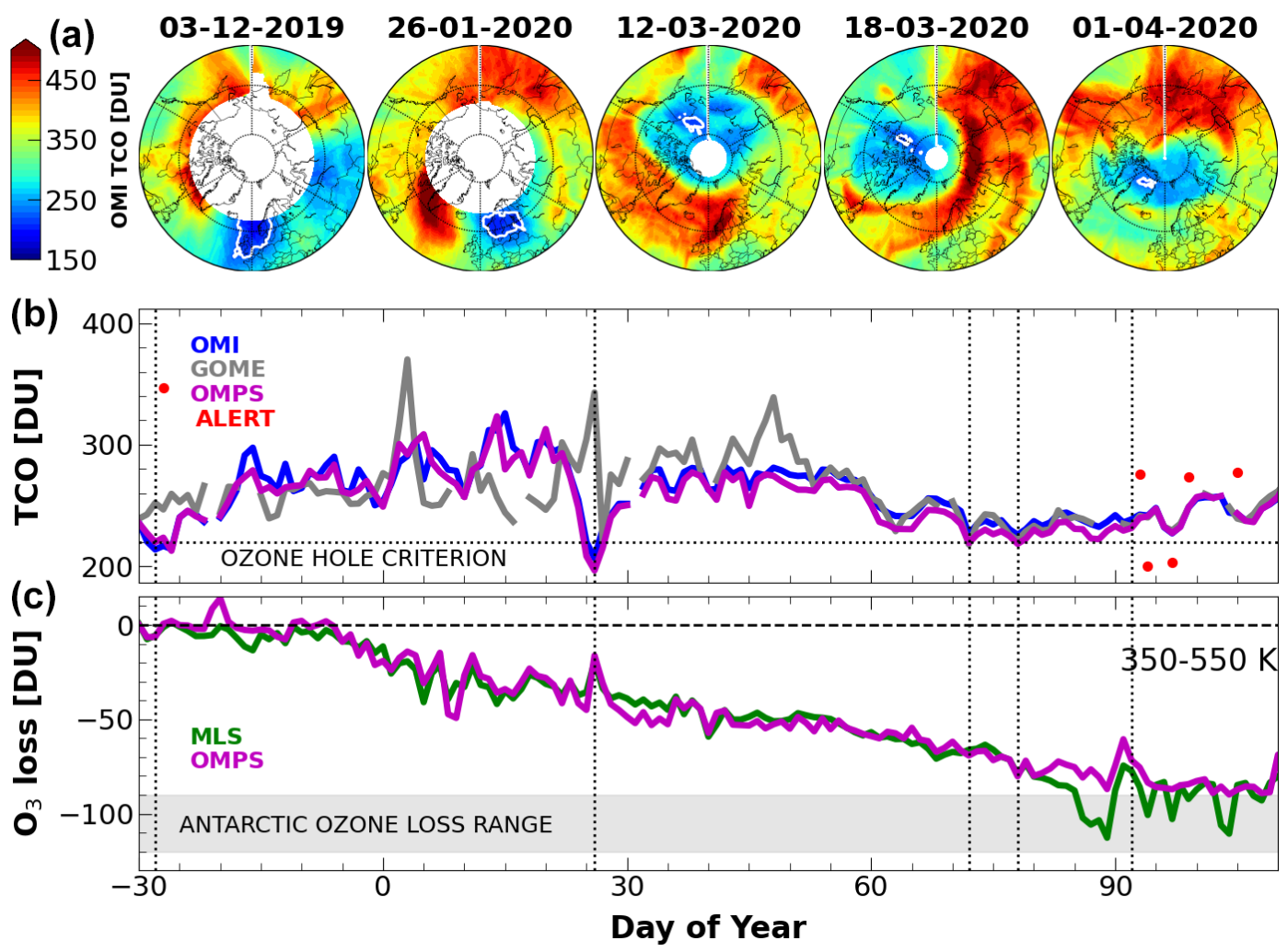

Figure 7. Arctic ozone in the total column and partial column ozone. (a) The maps of total column ozone from the OMI satellite measurements in the Arctic for selected ozone hole days for the winter of 2020. (b) The lowest (5\%) TCO measured inside the vortex from three different satellite measurements (OMI, GOME, and OMPS). The difference in total column measurements is due to the difference in coverage of the measurements in the Arctic region. The ozone hole criterion of $220 \mathrm{DU}$ is indicated by the dotted line. The total column ozone (TCO) measurements at Alert station are also shown (red solid circles). (c) The partial column ozone loss computed at the altitude range $350-550 \mathrm{~K}$ from the MLS and OMPS measurements. The ozone loss estimated in the Antarctic winters at the same altitude range is shown as the grey-coloured area.

rences based on OMPS and MERRA-2 data are given in Table S1 in the Supplement. The OMPS total column agrees well with that of the OMI measurements throughout the period, where the differences are mostly $2-3 \mathrm{DU}$ and are within the uncertainty of both instruments (i.e. about $5 \%-10 \%$ ). The OMPS measurements have captured all features of OMI measurements throughout the winter. The GOME measurements are very close to the OMI and OMPS measurements too but are slightly higher in January and February due to the limited coverage of northern polar region by GOME in winter months. As the winter progresses, the GOME coverage improves, and, therefore, the March and April measurements are in excellent agreement with other satellite observations. The TCO measurements at Alert also manifest the low ozone values of about $200 \mathrm{DU}$ in $2 \mathrm{~d}$ of April, corroborating the satellite observations (Fig. 7).

We also estimated the partial column ozone loss from the ozone profiles of OMPS and MLS satellites (Fig. 7, bottom panel). The ozone loss is calculated with respect to the passive method (Feng et al., 2005). The Arctic winters usually show TCO loss of about 70-80 DU in cold winters, about
45-50 DU in warm winters, and about 90-110 DU in exceptionally cold winters such as in 2005 and 2011 (Goutail et al., 2005; Kuttippurath et al., 2012; Rex et al., 2005; Manney et al., 2003). The largest column ozone loss deduced hitherto was in the Arctic winter of 2011 and was about 110 DU as assessed from all available studies (Griffin et al., 2019; Kuttippurath et al., 2012; Manney et al., 2011). On the other hand, the Antarctic ozone column loss is about twice that of the Arctic (about 150-160 DU) but slightly lower (about $100-120$ DU) in warm winters (1988 and 2002) and in early years (e.g. 1979-1985) of ozone loss there (Huck et al., 2005; Tilmes et al., 2006; Kuttippurath et al., 2015). The analyses suggest that even the partial column ozone loss in the Arctic winter of 2020 is about $115 \mathrm{DU}$ at $350-550 \mathrm{~K}$, which is higher than that of the Arctic winter of 2011 and similar to that of the loss found in the Antarctic winters of 1979-1985, 2002, and 2019.

Since the ozone loss in the Arctic winter of 2020 is up to the levels of that found in some Antarctic winters, we examined the occurrence of extremely low TCO values using data from OMPS and MERRA-2; the results are presented in 


\section{(a) EARLY YEARS OF ANTARCTIC OZONE LOSS}
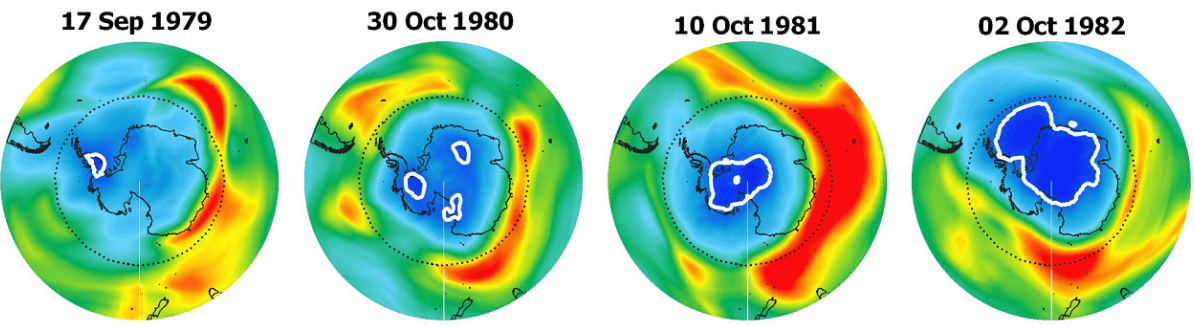

Total

Ozone

(DU)

(b)

OZONE MINI HOLES IN THE ARCTIC WINTER 2020
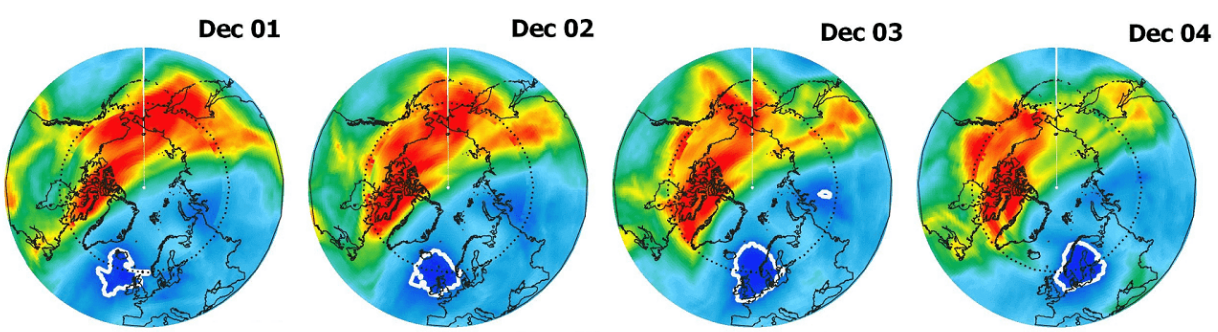

400

\section{(c) OZONE HOLE SIGNATURES IN THE ARCTIC WINTER 2020}
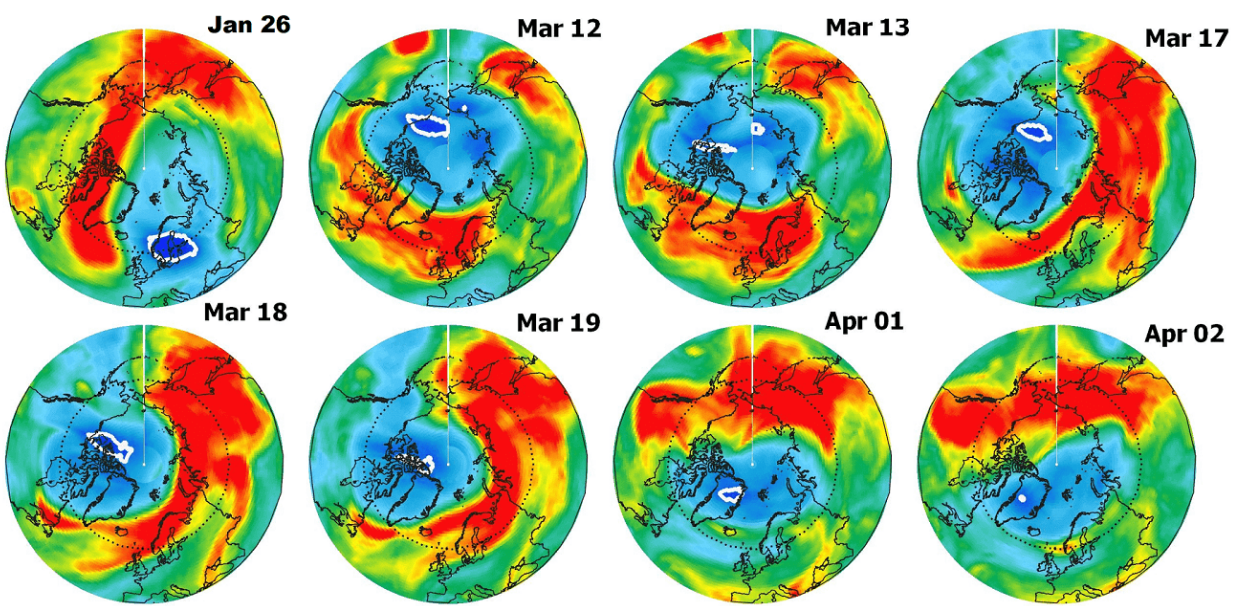

Figure 8. Maps of total column ozone from MERRA-2 and OMPS satellite measurements for selected days. The Antarctic ozone hole is defined as the area below 220 DU of ozone, as demarcated by the white contour. The top panel (a) shows the early years of the Antarctic ozone hole, the middle panel (b) shows the ozone mini-holes driven by dynamics, and the bottom panel (c) shows the ozone column observed in the Arctic winter of 2020.

Fig. 8 for selected days. The first appearance of ozone holes in Antarctic winters is also shown for comparison. There are clear and identifiable regions of extremely low TOC (regions below 220 DU) in March and April 2020, which were hundreds of kilometres wide (see also Dameris et al., 2021). The ozone maps show that the low-ozone regions in March and April 2020 were larger than those measured in the Antarctic in October 1979 and 1980. Therefore, ozone loss in the Arctic winter of 2020 is roughly comparable to the Antarctic ozone loss in 1980. The appearance of a threshold in TCO below 220 DU for several weeks demonstrates that Arctic winters may enter a new era of ozone depletion events (e.g. von der Gathen et al., 2021). However, extremely low TOC values neither appeared in all parts of the vortex nor are present continuously for months as they occur over the Antarctic; further, very strong chemical ozone loss occurs very regularly in the Antarctic, whereas strong Arctic ozone loss occurs only in very cold years (Bodeker et al., 2005; Tilmes 
et al., 2006; Feng et al., 2007; Müller et al., 2008; von der Gathen et al., 2021).

\section{Conclusions}

The Antarctic ozone hole has been present for the past 40 years, and the impact of the ozone hole on public health is mostly restricted to the southern high latitudes and midlatitudes. The ozone hole has also influenced the climate of the Southern Hemisphere by changing the winds, temperature, and precipitation in different regions. On the other hand, the biggest concern about the polar ozone loss in the stratosphere has always been strong Arctic ozone loss because such an ozone reduction can occur anywhere beyond $45^{\circ} \mathrm{N}$ in the densely populated northern midlatitudes and high latitudes. The changes in associated UV radiation incidence would also affect the flora and fauna of the region. If such a situation arose, it would trigger ecosystem damage and pose a serious threat to public health (e.g. Newman et al., 2001). An account of the record-breaking increase in UV radiation in the 2019/2020 Arctic winter is presented by Bernhard et al. (2020). Nevertheless, it is believed that extreme reductions in column ozone over the Arctic would be unlikely due to a relatively higher temperature and a shorter wintertime ozone loss period there. Furthermore, Arctic winters are always prone to several minor and frequent major warmings (almost one major warming per winter), which would restrict the lifetime of the polar vortex, PSC occurrence, and chlorine activation to limit the extent and severity of ozone loss. However, the Arctic winter of 2020 was exceptional as it was characterized by a strong vortex from December through to the end of April, large and widespread PSC occurrence, and unprecedented and prolonged chlorine activation with peak $\mathrm{ClO}$ values of about 2.0 ppbv. The high chlorine activation in early December and early January produced larger loss in ozone (e.g. 1-1.5 ppmv below $430 \mathrm{~K}$ in early January) in the Arctic that has never occurred before, consistent with the results of the studies of Weber et al. (2021) and Innes et al. (2020). The continued high chlorine activation from January to mid-April caused a record-breaking ozone loss of about $2.5-3.4$ ppmv at $400-600 \mathrm{~K}$ and triggered the first-ever observation of extremely low ozone columns in the Arctic in March and April 2020. The unprecedented chlorine activation (e.g. January through March, above $0.7 \mathrm{ppbv}$ ) and severe denitrification $(60 \%-80 \%)$ also set up the atmosphere to have the first ever occurrence of ozone loss saturation in the Arctic. Another interesting aspect of this winter were the dynamically driven but chemically modified ozone mini-holes in December and January. These mini-holes were larger than the Antarctic ozone holes of 1979 and the early 1980s. The analyses presented use multiple datasets, different ozone loss estimation methods, and several parameters to make robust statistics and a balanced assessment of the polar ozone depletion in the Arctic winter/spring of 2019/2020.
Code and data availability. The MLS data are available at https: //mls.jpl.nasa.gov/eos-aura-mls/data-access (Livesey et al., 2020). The ozonesonde data are available from the World Ozone and Ultraviolet Radiation Data Centre (WOUDC, https://woudc.org/ data/explore.php, https://doi.org/10.14287/10000008, WMO/GAW, 2020). The OMPS ozone data are available at https://disc.gsfc.nasa. gov/datasets/OMPS_NPP_LP_L2_O3_DAILY_2/ (Jaross, 2017) and https://disc.gsfc.nasa.gov/datasets/OMPS_NPP_NMTO3_L3_ DAILY_2/ (Deland, 2017). The OMI data are available at https: //disc.gsfc.nasa.gov/datasets/OMDOAO3G_003/ (Veefkind, 2012). The meteorological analyses, temperature, winds, heat flux, PSC, and wave heat flux data are taken from NASA Ozone Watch (https://ozonewatch.gsfc.nasa.gov/meteorology/, last access: 20 December 2020). The MERRA-2 data are accessed from https://disc. gsfc.nasa.gov/datasets/M2I3NPASM_5.12.4/ (GMAO, 2015). The GOME data are downloaded from https://atmosphere.copernicus. eu/data (Valks et al., 2014).

Supplement. The supplement related to this article is available online at: https://doi.org/10.5194/acp-21-14019-2021-supplement.

Author contributions. JK conceived the idea and wrote the original paper. The paper was subsequently revised with inputs from RM and WF. JK, PK, SR, RR, and GPG analysed the data and produced the figures. WF designed the model runs and carried out the model simulations. All authors participated in the discussions and made suggestions which were considered for the final draft.

Competing interests. Some authors are members of the editorial board of Atmospheric Chemistry and Physics. The peer-review process was guided by an independent editor, and the authors have also no other competing interests to declare.

Disclaimer. Publisher's note: Copernicus Publications remains neutral with regard to jurisdictional claims in published maps and institutional affiliations.

Acknowledgements. We thank the head of CORAL and the Director of the Indian Institute of Technology Kharagpur (IIT KGP), the Ministry of Human Resource Development (MHRD), and the Naval Research Board (OEP) of Defense Research and Development Organisation for facilitating the study. Pankaj Kumar acknowledges the support from MHRD and IIT KGP. Gopalakrishna Pillai Gopikrishnan, Sarath Raj, and Jayanarayanan Kuttippurath acknowledge funding from DRDO OEP. We thank the data managers and the scientists who worked hard to make available the MLS, OMPS, OMI, MERRA, ER5, ozonesonde, GOME, and all other data for this study. We also thank the HYSPLIT model developers for the trajectory analyses. The authors thank Paul Newman, Larry Flynn, Lucien Froidevaux, Jonathan Davies, Peter von der Gathen, and Martyn Chipperfield for their help and support in making this article happen. The authors thank Martyn Chipperfield for his suggestions and comments on the paper. The SLIMCAT forced by ERA5 
simulation was performed on the University of Leeds ARC4 HPC system.

Review statement. This paper was edited by Michel Van Roozendael and reviewed by two anonymous referees.

\section{References}

Bai, K., Liu, C., Shi, R., and Gao, W.: Comparison of SuomiNPP OMPS total column ozone with Brewer and Dobson spectrophotometers measurements, Front. Earth Sci., 93, 369-380, https://doi.org/10.1007/S11707-014-0480-5, 2015.

Bai, K., Chang, N. Bin, Yu, H., and Gao, W.: Statistical bias correction for creating coherent total ozone record from OMI and OMPS observations, Remote Sens. Environ., 182, 150-168, https://doi.org/10.1016/J.RSE.2016.05.007, 2016.

Bais, A. F., Lucas, R. M., Bornman, J. F., Williamson, C. E., Sulzberger, B., Austin, A. T., Wilson, S. R., Andrady, A. L., Bernhard, G., McKenzie, R. L., Aucamp, P. J., Madronich, S., Neale, R. E., Yazar, S., Young, A. R., de Gruijl, F. R., Norval, M., Takizawa, Y., Barnes, P. W., Robson, T. M., Robinson, S. A., Ballaré, C. L., Flint, S. D., Neale, P. J., Hylander, S., Rose, K. C., Wängberg, S.-Å., Häder, D.-P., Worrest, R. C., Zepp, R. G., Paul, N. D., Cory, R. M., Solomon, K. R., Longstreth, J., Pandey, K. K., Redhwi, H. H., Torikai, A., and Heikkilä, A. M.: Environmental effects of ozone depletion, UV radiation and interactions with climate change: UNEP Environmental Effects Assessment Panel, update 2017, Photochem. Photobiol. Sci., 17, 127-179, https://doi.org/10.1039/C7PP90043K, 2018.

Bernhard, G. H., Fioletov, V. E., Grooß, J.-U., Ialongo, I., Johnsen, B., Lakkala, K., Manney, G. L., Müller, R., and Svendby, T.: Record-Breaking Increases in Arctic Solar Ultraviolet Radiation Caused by Exceptionally Large Ozone Depletion in 2020, Geophys. Res. Lett., 47, e2020GL090844, https://doi.org/10.1029/2020GL090844, 2020.

Bodeker, G. E., Shiona, H., and Eskes, H.: Indicators of Antarctic ozone depletion, Atmos. Chem. Phys., 5, 2603-2615, https://doi.org/10.5194/acp-5-2603-2005, 2005.

Bognar, K., Alwarda, R., Strong, K., Chipperfield, M. P., Dhomse, S. S., Drummond, J. R., Feng, W., Fioletov, V., Goutail, F., Herrera, B., Manney, G. L., McCullough, E. M., Millán, L. F., Pazmino, A., Walker, K. A., Wizenberg, T. and Zhao, X.: Unprecedented Spring 2020 Ozone Depletion in the Context of 20 Years of Measurements at Eureka, Canada, J. Geophys. Res.-Atmos., 126, e2020JD034365, https://doi.org/10.1029/2020JD034365, 2021.

Bojkov, R. D. and Balis, D. S.: Characteristics of episodes with extremely low ozone values in the northern middle latitudes 1957-2000, Ann. Geophys., 19, 797-807, https://doi.org/10.5194/angeo-19-797-2001, 2001.

Canziani, P. O., Compagnucci, R. H., Bischoff, S. A., and Legnani, W. E.: A study of impacts of tropospheric synoptic processes on the genesis and evolution of extreme total ozone anomalies over southern South America, J. Geophys. Res.-Atmos., 107, ACL 21-ACL 2-25, https://doi.org/10.1029/2001JD000965, 2002.

Chipperfield, M. P.: New version of the TOMCAT/SLIMCAT offline chemical transport model: Intercomparison of stratospheric tracer experiments, Q. J. Roy. Meteor. Soc., 132, 1179-1203, https://doi.org/10.1256/QJ.05.51, 2006.

Chipperfield, M. P., Feng, W. and Rex, M.: Arctic ozone loss and climate sensitivity: Updated threedimensional model study, Geophys. Res. Lett., 32, L11813, https://doi.org/10.1029/2005GL022674, 2005.

Chipperfield, M. P., Bekki, S., Dhomse, S., Harris, N. R. P., Hassler, B., Hossaini, R., Steinbrecht, W., Thiéblemont, R., and Weber, M.: Detecting recovery of the stratospheric ozone layer, Nature, 549, 211-218, https://doi.org/10.1038/nature23681, 2017.

Chubachi, S.: Preliminary result of ozone observations at Syowa from February 1982 to January 1983, Mem. Natl Inst. Polar Res., Special Issue, 34, 13-19, 1984.

Coy, L., Nash, E. R., and Newman, P. A.: Meteorology of the polar vortex: Spring 1997, Geophys. Res. Lett., 24, 2693-2696, https://doi.org/10.1029/97GL52832, 1997.

Dameris, M., Loyola, D. G., Nützel, M., Coldewey-Egbers, M., Lerot, C., Romahn, F., and van Roozendael, M.: Record low ozone values over the Arctic in boreal spring 2020, Atmos. Chem. Phys., 21, 617-633, https://doi.org/10.5194/acp-21-6172021, 2021.

De Laat, A. T. J. and Van Weele, M.: The 2010 Antarctic ozone hole: Observed reduction in ozone destruction by minor sudden stratospheric warmings, Sci. Rep., 1, https://doi.org/10.1038/srep00038, 2011.

Deland, M.: OMPS-NPP L2 LP Ozone (O3) Vertical Profile swath daily 3slit V2.5, Greenbelt, MD, USA, Goddard Earth Sciences Data and Information Services Center (GES DISC) [data set], https://doi.org/10.5067/X1Q9VA07QDS7, 2017.

DeLand, M. T., Bhartia, P. K., Kramarova, N. and Chen, Z.: OMPS LP Observations of PSC Variability During the NH 2019-2020 Season, Geophys. Res. Lett., 47, e2020GL090216, https://doi.org/10.1029/2020GL090216, 2020.

Dhomse, S. S., Feng, W., Montzka, S. A., Hossaini, R., Keeble, J., Pyle, J. A., Daniel, J. S. and Chipperfield, M. P.: Delay in recovery of the Antarctic ozone hole from unexpected CFC-11 emissions, Nat. Commun., 101, 1-12, https://doi.org/10.1038/s41467-019-13717-x, 2019.

Dobson, B. G. and Harrison, D. N.: Measurements of the amount of ozone in the earth's atmosphere and its relation to other geophysical conditions, Proc. R. Soc. London. Ser. A, 110, 660-693, https://doi.org/10.1098/RSPA.1926.0040, 1926.

Drdla, K. and Müller, R.: Temperature thresholds for chlorine activation and ozone loss in the polar stratosphere, Ann. Geophys., 30, 1055-1073, https://doi.org/10.5194/angeo-30-10552012, 2012.

Engel, A., Bönisch, H., Ostermöller, J., Chipperfield, M. P., Dhomse, S., and Jöckel, P.: A refined method for calculating equivalent effective stratospheric chlorine, Atmos. Chem. Phys., 18, 601-619, https://doi.org/10.5194/acp-18-601-2018, 2018.

Farman, J. C., Gardiner, B. G., and Shanklin, J. D.: Large losses of total ozone in Antarctica reveal seasonal ClOx/NOx interaction, Nature, 315, 207-210, https://doi.org/10.1038/315207a0, 1985.

Feng, W.: Fast Ozone Loss Around the Polar Vortex During 2002/2003 Arctic Winter Deep Minihole Event, Water Air Soil Pollut., 171, 383-397, https://doi.org/10.1007/S11270-0059058-X, 2006.

Feng, W., Chipperfield, M. P., Roscoe, H. K., Remedios, J. J., Waterfall, A. M., Stiller, G. P., Glatthor, N., Höpfner, M., and Wang, 
D.-Y.: Three-Dimensional Model Study of the Antarctic Ozone Hole in 2002 and Comparison with 2000, J. Atmos. Sci., 62, 822837, https://doi.org/10.1175/JAS-3335.1, 2005.

Feng, W., Chipperfield, M. P., Davies, S., von der Gathen, P., Kyrö, E., Volk, C. M., Ulanovsky, A., and Belyaev, G.: Large chemical ozone loss in 2004/2005 Arctic winter/spring, Geophys. Res. Lett., 34, 9803, https://doi.org/10.1029/2006GL029098, 2007.

Feng, W., Chipperfield, M. P., Davies, S., Mann, G. W., Carslaw, K. S., Dhomse, S., Harvey, L., Randall, C., and Santee, M. L.: Modelling the effect of denitrification on polar ozone depletion for Arctic winter 2004/2005, Atmos. Chem. Phys., 11, 6559-6573, https://doi.org/10.5194/acp-11-6559-2011, 2011.

Feng, W., Dhomse, S. S., Arosio, C., Weber, M., Burrows, J. P., Santee, M. L., and Chipperfield, M. P.: Arctic Ozone Depletion in 2019/20: Roles of Chemistry, Dynamics and the Montreal Protocol, Geophys. Res. Lett., 48, e2020GL091911, https://doi.org/10.1029/2020GL091911, 2021.

Flynn, L., Long, C., Wu, X., Evans, R., Beck, C. T., Petropavlovskikh, I., McConville, G., Yu, W., Zhang, Z., Niu, J., Beach, E., Hao, Y., Pan, C., Sen, B., Novicki, M., Zhou, S., and Seftor, C.: Performance of the Ozone Mapping and Profiler Suite (OMPS) products, J. Geophys. Res.-Atmos., 119, 61816195, https://doi.org/10.1002/2013JD020467, 2014.

Froidevaux, L., Jiang, Y. B., Lambert, A., Livesey, N. J., Read, W. G., Waters, J. W., Browell, E. V., Hair, J. W., Avery, M. A., McGee, T. J., Twigg, L. W., Sumnicht, G. K., Jucks, K. W., Margitan, J. J., Sen, B., Stachnik, R. A., Toon, G. C., Bernath, P. F., Boone, C. D., Walker, K. A., Filipiak, M. J., Harwood, R. S., Fuller, R. A., Manney, G. L., Schwartz, M. J., Daffer, W. H., Drouin, B. J., Cofield, R. E., Cuddy, D. T., Jarnot, R. F., Knosp, B. W., Perun, V. S., Snyder, W. V., Stek, P. C., Thurstans, R. P. and Wagner, P. A.: Validation of Aura Microwave Limb Sounder stratospheric ozone measurements, J. Geophys. Res. Atmos., 113, 15-20, https://doi.org/10.1029/2007JD008771, 2008.

Gelaro, R., McCarty, W., Suárez, M. J., Todling, R., Molod, A., Takacs, L., Randles, C. A., Darmenov, A., Bosilovich, M. G., Reichle, R., Wargan, K., Coy, L., Cullather, R., Draper, C., Akella, S., Buchard, V., Conaty, A., da Silva, A. M., Gu, W., Kim, G. K., Koster, R., Lucchesi, R., Merkova, D., Nielsen, J. E., Partyka, G., Pawson, S., Putman, W., Rienecker, M., Schubert, S. D., Sienkiewicz, M., and Zhao, B.: The modern-era retrospective analysis for research and applications, version 2 (MERRA-2), J. Climate, 30, 5419-5454, https://doi.org/10.1175/JCLI-D-160758.1, 2017.

Global Modeling and Assimilation Office (GMAO): MERRA2 inst3_3d_asm_Np: 3d,3-Hourly,Instantaneous,PressureLevel,Assimilation,Assimilated Meteorological Fields V5.12.4, Greenbelt, MD, USA, Goddard Earth Sciences Data and Information Services Center (GES DISC) [data set], https://doi.org/10.5067/QBZ6MG944HW0, 2015.

Goutail, F., Pommereau, J.-P., Lefèvre, F., van Roozendael, M., Andersen, S. B., Kåstad Høiskar, B.-A., Dorokhov, V., Kyrö, E., Chipperfield, M. P., and Feng, W.: Early unusual ozone loss during the Arctic winter 2002/2003 compared to other winters, Atmos. Chem. Phys., 5, 665-677, https://doi.org/10.5194/acp-5665-2005, 2005.

Griffin, D., Walker, K. A., Wohltmann, I., Dhomse, S. S., Rex, M., Chipperfield, M. P., Feng, W., Manney, G. L., Liu, J., and Tarasick, D.: Stratospheric ozone loss in the Arctic winters between
2005 and 2013 derived with ACE-FTS measurements, Atmos. Chem. Phys., 19, 577-601, https://doi.org/10.5194/acp-19-5772019, 2019.

Grooß, J.-U. and Müller, R.: Simulation of Record Arctic Stratospheric Ozone Depletion in 2020, J. Geophys. Res.-Atmos., 126, e2020JD033339, https://doi.org/10.1029/2020JD033339, 2021.

Huck, P. E., Mcdonald, A. J., Bodeker, G. E., Struthers, H., and Huck, C.: Interannual variability in Antarctic ozone depletion controlled by planetary waves and polar temperature, Geophys. Res. Lett., 32, L13819, https://doi.org/10.1029/2005GL022943, 2005.

Hurwitz, M. M., Newman, P. A., and Garfinkel, C. I.: The Arctic vortex in March 2011: a dynamical perspective, Atmos. Chem. Phys., 11, 11447-11453, https://doi.org/10.5194/acp-11-114472011, 2011.

Inness, A., Chabrillat, S., Flemming, J., Huijnen, V., Langenrock, B., Nicolas, J., Polichtchouk, I., and Razinger, M.: Exceptionally Low Arctic Stratospheric Ozone in Spring 2020 as Seen in the CAMS Reanalysis, J. Geophys. Res.-Atmos., 125, e2020JD033563, https://doi.org/10.1029/2020JD033563, 2020.

IPCC: Climate Change 2007: Mitigation. Contribution of Working Group III to the Fourth Assessment Report of the Intergovernmental Panel on Climate Change, edited by: Metz, B., Davidson, O. R., Bosch, P. R., Dave, R., and Meyer, L. A., Cambridge University Press, Cambridge, United Kingdom and New York, NY, USA, 2007.

James, P. M.: A climatology of ozone mini-holes over the northern hemisphere, Int. J. Climatol., $\quad 18(12), \quad$ https://doi.org/10.1002/(SICI)10970088(1998100)18:12<1287::AID-JOC315>3.0.CO;2-4, 1998.

James, P. M., Peters, D., and Greisiger, K. M.: A study of ozone mini-hole formation using a tracer advection model driven by barotropic dynamics, Meteorol. Atmos. Phys., 64, 107-121, https://doi.org/10.1007/bf01044132, 1997.

Jaross, G.: OMPS-NPP L3 NM Ozone (O3) Total Column $1.0 \mathrm{deg}$ grid daily V2, Greenbelt, MD, USA, Goddard Earth Sciences Data and Information Services Center (GES DISC) [data set], https://doi.org/10.5067/7Y7KSA1QNQP8, 2017.

Jiang, Y., Yung, Y. L., and Zurek, R. W.: Decadal evolution of the Antarctic ozone hole, J. Geophys. Res.-Atmos., 101, 8985-8999, https://doi.org/10.1029/96jd00063, 1996.

Jin, J. J., Semeniuk, K., Manney, G. L., Jonsson, A. I., Beagley, S. R., McConnell, J. C., Dufour, G., Nassar, R., Boone, C. D., Walker, K. A., Bernath, P. F., and Rinsland, C. P.: Severe Arctic ozone loss in the winter 2004/2005: Observations from ACE-FTS, Geophys. Res. Lett., 33, L15801, https://doi.org/10.1029/2006GL026752, 2006.

Kirner, O., Müller, R., Ruhnke, R., and Fischer, H.: Contribution of liquid, NAT and ice particles to chlorine activation and ozone depletion in Antarctic winter and spring, Atmos. Chem. Phys., 15, 2019-2030, https://doi.org/10.5194/acp-15-2019-2015, 2015.

Kivi, R., Kyrö, E., Turunen, T., Harris, N. R. P., von der Gathen, P., Rex, M., Andersen, S. B., and Wohltmann, I.: Ozonesonde observations in the Arctic during 1989-2003: Ozone variability and trends in the lower stratosphere and free troposphere, J. Geophys. Res.-Atmos., 112, https://doi.org/10.1029/2006JD007271, 2007.

Kramarova, N. A., Nash, E. R., Newman, P. A., Bhartia, P. K., McPeters, R. D., Rault, D. F., Seftor, C. J., Xu, P. Q., and Labow, G. J.: Measuring the Antarctic ozone hole with the new Ozone 
Mapping and Profiler Suite (OMPS), Atmos. Chem. Phys., 14, 2353-2361, https://doi.org/10.5194/acp-14-2353-2014, 2014.

Kroon, M., Veefkind, J. P., Sneep, M., McPeters, R. D., Bhartia, P. K., and Levelt, P. F.: Comparing OMI-TOMS and OMI-DOAS total ozone column data, J. Geophys. Res.-Atmos., 113, D16S28, https://doi.org/10.1029/2007JD008798, 2008.

Krzyścin, J. W.: Long-term changes in ozone mini-hole event frequency over the Northern Hemisphere derived from ground-based measurements, Int. J. Climatol., 22, 1425-1439, https://doi.org/10.1002/joc.812, 2002.

Kuttippurath, J., Godin-Beekmann, S., Lefèvre, F., and Goutail, F.: Spatial, temporal, and vertical variability of polar stratospheric ozone loss in the Arctic winters 2004/2005-2009/2010, Atmos. Chem. Phys., 10, 9915-9930, https://doi.org/10.5194/acp10-9915-2010, 2010.

Kuttippurath, J., Kleinböhl, A., Sinnhuber, M., Bremer, H., Küllmann, H., Notholt, J., Godin-Beekmann, S., Tripathi, O., and Nikulin, G.: Arctic ozone depletion in 20022003 measured by ASUR and comparison with POAM observations, J. Geophys. Res.-Atmos., 116, D22305, https://doi.org/10.1029/2011JD016020, 2011.

Kuttippurath, J., Godin-Beekmann, S., Lefèvre, F., Nikulin, G., Santee, M. L., and Froidevaux, L.: Record-breaking ozone loss in the Arctic winter 2010/2011: comparison with 1996/1997, Atmos. Chem. Phys., 12, 7073-7085, https://doi.org/10.5194/acp12-7073-2012, 2012.

Kuttippurath, J., Lefèvre, F., Pommereau, J.-P., Roscoe, H. K., Goutail, F., Pazmiño, A., and Shanklin, J. D.: Antarctic ozone loss in 1979-2010: first sign of ozone recovery, Atmos. Chem. Phys., 13, 1625-1635, https://doi.org/10.5194/acp-131625-2013, 2013.

Kuttippurath, J., Godin-Beekmann, S., Lefèvre, F., Santee, M. L., Froidevaux, L., and Hauchecorne, A.: Variability in Antarctic ozone loss in the last decade (2004-2013): high-resolution simulations compared to Aura MLS observations, Atmos. Chem. Phys., 15, 10385-10397, https://doi.org/10.5194/acp-15-103852015, 2015.

Kuttippurath, J., Kumar, P., Nair, P. J., and Pandey, P. C.: Emergence of ozone recovery evidenced by reduction in the occurrence of Antarctic ozone loss saturation, npj Clim. Atmos. Sci., 1, 42, https://doi.org/10.1038/s41612-018-0052-6, 2018.

Lawrence, Z. D., Perlwitz, J., Butler, A. H., Manney, G. L., Newman, P. A., Lee, S. H., and Nash, E. R.: The Remarkably Strong Arctic Stratospheric Polar Vortex of Winter 2020: Links to Record-Breaking Arctic Oscillation and Ozone Loss, J. Geophys. Res.-Atmos., 125, e2020JD033271, https://doi.org/10.1029/2020JD033271, 2020.

Lindenmaier, R., Strong, K., Batchelor, R. L., Chipperfield, M. P., Daffer, W. H., Drummond, J. R., Duck, T. J., Fast, H., Feng, W., Fogal, P. F., Kolonjari, F., Manney, G. L., Manson, A., Meek, C., Mittermeier, R. L., Nott, G. J., Perro, C., and Walker, K. A.: Unusually low ozone, $\mathrm{HCl}$, and $\mathrm{HNO}_{3}$ column measurements at Eureka, Canada during winter/spring 2011, Atmos. Chem. Phys., 12, 3821-3835, https://doi.org/10.5194/acp12-3821-2012, 2012.

Livesey, N. J., Santee, M. L., and Manney, G. L.: A Matchbased approach to the estimation of polar stratospheric ozone loss using Aura Microwave Limb Sounder observations, At- mos. Chem. Phys., 15, 9945-9963, https://doi.org/10.5194/acp15-9945-2015, 2015.

Livesey, N. J., Read, W. G., Wagner, P. A., Froidevaux, L., Lambert, A., Manney, G. L., Valle, L. F. M., Pumphrey, H. C., Santee, M. L., Schwartz, M. J., Wang, S., Fuller, R. A., Jarnot, R. F., Knosp, B. W., Martinez, E., and Lay, R. R.: Version 4.2x Level 2 and 3 data quality and description document, available at: https:// mls.jpl.nasa.gov/data/v4-2_data_quality_document.pdf, last access: 20 December 2020.

Loyola, D. G., Koukouli, M. E., Valks, P., Balis, D. S., Hao, N., Van Roozendael, M., Spurr, R. J. D., Zimmer, W., Kiemle, S., Lerot, C., and Lambert, J. C.: The GOME-2 total column ozone product: Retrieval algorithm and groundbased validation, J. Geophys. Res.-Atmos., 116, D07302, https://doi.org/10.1029/2010JD014675, 2011.

Manney, G. L., Froidevaux, L., Santee, M. L., Livesey, N. J., Sabutis, J. L., and Waters, J. W.: Variability of ozone loss during Arctic winter (1991-2000) estimated from UARS Microwave Limb Sounder measurements, J. Geophys. Res.-Atmos., 108, 4149, https://doi.org/10.1029/2002jd002634, 2003.

Manney, G. L., Santee, M. L., Rex, M., Livesey, N. J., Pitts, M. C., Veefkind, P., Nash, E. R., Wohltmann, I., Lehmann, R., Froidevaux, L., Poole, L. R., Schoeberl, M. R., Haffner, D. P., Davies, J., Dorokhov, V., Gernandt, H., Johnson, B., Kivi, R., Kyrö, E., Larsen, N., Levelt, P. F., Makshtas, A., McElroy, C. T., Nakajima, H., Parrondo, M. C., Tarasick, D. W., Von Der Gathen, P., Walker, K. A., and Zinoviev, N. S.: Unprecedented Arctic ozone loss in 2011, Nature, 478, 469-475, https://doi.org/10.1038/nature10556, 2011.

Manney, G. L., Livesey, N. J., Santee, M. L., Froidevaux, L., Lambert, A., Lawrence, Z. D., Millán, L. F., Neu, J. L., Read, W. G., Schwartz, M. J., and Fuller, R. A.: RecordLow Arctic Stratospheric Ozone in 2020: MLS Observations of Chemical Processes and Comparisons with Previous Extreme Winters, Geophys. Res. Lett., 47, e2020GL089063, https://doi.org/10.1029/2020GL089063, 2020.

McKenna, D. S., Jones, R. L., Austin, J., Browell, E. V., McCormick, M. P., Krueger, A. J. and Tuck, A. F.: Diagnostic studies of the Antarctic vortex during the 1987 Airborne Antarctic Ozone Experiment: Ozone miniholes, J. Geophys. Res.-Atmos., 94, 11641-11668, https://doi.org/10.1029/JD094ID09P11641, 1989.

Millán, L. F. and Manney, G. L.: An assessment of ozone mini-hole representation in reanalyses over the Northern Hemisphere, Atmos. Chem. Phys., 17, 9277-9289, https://doi.org/10.5194/acp17-9277-2017, 2017.

Müller, R., Grooß, J.-U., Lemmen, C., Heinze, D., Dameris, M., and Bodeker, G.: Simple measures of ozone depletion in the polar stratosphere, Atmos. Chem. Phys., 8, 251-264, https://doi.org/10.5194/acp-8-251-2008, 2008.

Nair, P. J., Froidevaux, L., Kuttippurath, J., Zawodny, J. M., Russell, J. M., Steinbrecht, W., Claude, H., Leblanc, T., van Gijsel, J. A. E., Johnson, B., Swart, D. P. J., Thomas, A., Querel, R., Wang, R., and Anderson, J.: Subtropical and midlatitude ozone trends in the stratosphere: Implications for recovery, J. Geophys. Res., 120, 7247-7257, https://doi.org/10.1002/2014JD022371, 2015.

Nash, E. R., Newman, P. A., Rosenfield, J. E., and Schoeberl, M. R.: An objective determination of the polar vortex using Ertel's 
potential vorticity, J. Geophys. Res.-Atmos., 101, 9471-9478, https://doi.org/10.1029/96JD00066, 1996.

Newman, P. A., Lait, L. R., and Schoeberl, M. R.: The morphology and meteorology of southern hemisphere spring total ozone mini-holes, Geophys. Res. Lett., 15, 923-926, https://doi.org/10.1029/GL015i008p00923, 1988.

Newman, P. A., Nash, E. R., and Rosenfield, J. E.: What controls the temperature of the Arctic stratosphere during the spring?, J. Geophys. Res.-Atmos., 106, 19999-20010, https://doi.org/10.1029/2000JD000061, 2001.

Newman, P. A., Daniel, J. S., Waugh, D. W., and Nash, E. R.: A new formulation of equivalent effective stratospheric chlorine (EESC), Atmos. Chem. Phys., 7, 4537-4552, https://doi.org/10.5194/acp-7-4537-2007, 2007.

Newman, P. A., Oman, L. D., Douglass, A. R., Fleming, E. L., Frith, S. M., Hurwitz, M. M., Kawa, S. R., Jackman, C. H., Krotkov, N. A., Nash, E. R., Nielsen, J. E., Pawson, S., Stolarski, R. S. and Velders, G. J. M.: What would have happened to the ozone layer if chlorofluorocarbons (CFCs) had not been regulated?, Atmos. Chem. Phys., 9, 2113-2128, https://doi.org/10.5194/acp-9-21132009, 2009.

Peters, D., Egger, J., and Entzian, G.: Dynamical aspects of ozone mini-hole formation, Meteorol. Atmos. Phys., 55, 205-214, https://doi.org/10.1007/BF01029827, 1995.

Pitts, M. C., Poole, L. R., and Thomason, L. W.: CALIPSO polar stratospheric cloud observations: second-generation detection algorithm and composition discrimination, Atmos. Chem. Phys., 9, 7577-7589, https://doi.org/10.5194/acp-9-7577-2009, 2009.

Pommereau, J. P., Goutail, F., Pazmino, A., Lefèvre, F., Chipperfield, M. P., Feng, W., Van Roozendael, M., Jepsen, N., Hansen, G., Kivi, R., Bognar, K., Strong, K., Walker, K., Kuzmichev, A., Khattatov, S. and Sitnikova, V.: Recent Arctic ozone depletion: Is there an impact of climate change?, CR Geosci., 350, 347-353, https://doi.org/10.1016/j.crte.2018.07.009, 2018.

Rao, J. and Garfinkel, C. I.: Arctic Ozone Loss in March 2020 and its Seasonal Prediction in CFSv2: A Comparative Study With the 1997 and 2011 Cases, J. Geophys. Res.-Atmos., 125, e2020JD033524, https://doi.org/10.1029/2020JD033524, 2020.

Reed, R. J.: The role of vertical motions in ozone-weather relationships, J. Meteorol., 7, 263-267, 1950.

Rex, M., Salawitch, R. J., Harris, N. R. P., Gathen, P. von der, Braathen, G. O., Schulz, A., Deckelmann, H., Chipperfield, M., Sinnhuber, B.-M., Reimer, E., Alfier, R., Bevilacqua, R., Hoppel, K., Fromm, M., Lumpe, J., Küllmann, H., Kleinböhl, A., Bremer, H., König, M. von, Künzi, K., Toohey, D., Vömel, H., Richard, E., Aikin, K., Jost, H., Greenblatt, J. B., Loewenstein, M., Podolske, J. R., Webster, C. R., Flesch, G. J., Scott, D. C., Herman, R. L., Elkins, J. W., Ray, E. A., Moore, F. L., Hurst, D. F., Romashkin, P., Toon, G. C., Sen, B., Margitan, J. J., Wennberg, P., Neuber, R., Allart, M., Bojkov, B. R., Claude, H., Davies, J., Davies, W., Backer, H. De, Dier, H., Dorokhov, V., Fast, H., Kondo, Y., Kyrö, E., Litynska, Z., Mikkelsen, I. S., Molyneux, M. J., Moran, E., Nagai, T., Nakane, H., Parrondo, C., Ravegnani, F., Skrivankova, P., Viatte, P., and Yushkov, V.: Chemical depletion of Arctic ozone in winter 1999/2000, J. Geophys. Res.-Atmos., 107, L04116, https://doi.org/10.1029/2001JD000533, 2002.

Rex, M., Salawitch, R. J., von der Gathen, P., Harris, N. R. P., Chipperfield, M. P., and Naujokat, B.: Arctic ozone loss and climate change, Geophys. Res. Lett., 31, L04116, https://doi.org/10.1029/2003GL018844, 2004.

Rieder, H. E. and Polvani, L. M.: Are recent Arctic ozone losses caused by increasing greenhouse gases?, Geophys. Res. Lett., 40, 4437-4441, https://doi.org/10.1002/GRL.50835, 2013.

Riese, M., Ploeger, F., Rap, A., Vogel, B., Konopka, P., Dameris, M., and Forster, P.: Impact of uncertainties in atmospheric mixing on simulated UTLS composition and related radiative effects, J. Geophys. Res.-Atmos., 117, 16305, https://doi.org/10.1029/2012JD017751, 2012.

Salby, M., Titova, E., and Deschamps, L.: Rebound of antarctic ozone, Geophys. Res. Lett., 38, L09702, https://doi.org/10.1029/2011GL047266, 2011.

Santee, M. L., Manney, G. L., Froidevaux, L., Zurek, R. W., and Waters, J. W.: MLS observations of $\mathrm{ClO}$ and $\mathrm{HNO}_{3}$ in the 199697 Arctic polar vortex, Geophys. Res. Lett., 24, 2713-2716, https://doi.org/10.1029/97GL52830, 1997.

Sinnhuber, B. M., Chipperfield, M. P., Davies, S., Burrows, J. P., Eichmann, K. U., Weber, M., Von Der Gathen, P., Guirlet, M., Cahill, G. A., Lee, A. M., and Pyle, J. A.: Large loss of total ozone during the Arctic winter of 1999/2000, Geophys. Res. Lett., 27, 3473-3476, https://doi.org/10.1029/2000GL011772, 2000.

Smit, H. G. J., Straeter, W., Johnson, B. J., Oltmans, S. J., Davies, J., Tarasick, D. W., Hoegger, B., Stubi, R., Schmidlin, F. J., Northam, T., Thompson, A. M., Witte, J. C., Boyd, I., and Posny, F.: Assessment of the performance of ECC-ozonesondes under quasi-flight conditions in the environmental simulation chamber: Insights from the Juelich Ozone Sonde Intercomparison Experiment (JOSIE), J. Geophys. Res.-Atmos., 112, D19306, https://doi.org/10.1029/2006JD007308, 2007.

Solomon, S., Portmann, R. W., Sasaki, T., Hofmann, D. J., and Thompson, D. W. J.: Four decades of ozonesonde measurements over Antarctica, J. Geophys. Res., 110, D21311, https://doi.org/10.1029/2005jd005917, 2005.

Solomon, S., Ivy, D. J., Kinnison, D., Mills, M. J., Neely, R. R., and Schmidt, A.: Emergence of healing in the Antarctic ozone layer, Science 353, 269-274, https://doi.org/10.1126/science.aae0061, 2016.

Sonkaew, T., von Savigny, C., Eichmann, K.-U., Weber, M., Rozanov, A., Bovensmann, H., Burrows, J. P., and Grooß, J.-U.: Chemical ozone losses in Arctic and Antarctic polar winter/spring season derived from SCIAMACHY limb measurements 2002-2009, Atmos. Chem. Phys., 13, 1809-1835, https://doi.org/10.5194/acp-13-1809-2013, 2013.

Spang, R., Hoffmann, L., Müller, R., Grooß, J.-U., Tritscher, I., Höpfner, M., Pitts, M., Orr, A., and Riese, M.: A climatology of polar stratospheric cloud composition between 2002 and 2012 based on MIPAS/Envisat observations, Atmos. Chem. Phys., 18, 5089-5113, https://doi.org/10.5194/acp-18-5089-2018, 2018.

Steinbrecht, W., Hassler, B., Claude, H., Winkler, P., and Stolarski, R. S.: Global distribution of total ozone and lower stratospheric temperature variations, Atmos. Chem. Phys., 3, 14211438, https://doi.org/10.5194/acp-3-1421-2003, 2003.

Stenke, A. and Grewe, V.: Impact of ozone mini-holes on the heterogeneous destruction of stratospheric ozone, Chemosphere, 50, 177-190, https://doi.org/10.1016/S0045-6535(02)00599-4, 2003. 
Strahan, S. E. and Douglass, A. R.: Decline in Antarctic Ozone Depletion and Lower Stratospheric Chlorine Determined From Aura Microwave Limb Sounder Observations, Geophys. Res. Lett., 45, 382-390, https://doi.org/10.1002/2017GL074830, 2018.

Tilmes, S., Müller, R., Engel, A., Rex, M., and Russell, J. M.: Chemical ozone loss in the Arctic and Antarctic stratosphere between 1992 and 2005, Geophys. Res. Lett., 33, L20812, https://doi.org/10.1029/2006GL026925, 2006.

Tilmes, S., Müller, R., Salawitch, R. J., Schmidt, U., Webster, C. R., Oelhaf, H., Camy-Peyret, C. C., and Russell III, J. M.: Chemical ozone loss in the Arctic winter 1991-1992, Atmos. Chem. Phys., 8, 1897-1910, https://doi.org/10.5194/acp-8-1897-2008, 2008.

Valks, P., Loyola, D., Zimmer, W., Kiemle, S., and Ruppert, T.: Product User Manual for GOME Total Column Products of Ozone, $\mathrm{NO}_{2}$, tropospheric $\mathrm{NO}_{2}, \mathrm{BrO}, \mathrm{SO}_{2}, \mathrm{H}_{2} \mathrm{O}, \mathrm{HCHO}$, $\mathrm{OClO}$ and Cloud Properties, DLR/GOME/PUM/01, Iss./Rev. 2/G, available at: https://atmosphere.copernicus.eu/data (last access: 20 December 2020), 2014.

Veefkind, P.: OMI/Aura Ozone (O3) DOAS Total Column Daily L2 Global Gridded 0.25 degree $\mathrm{x} \quad 0.25$ degree V3, Greenbelt, MD, USA, Goddard Earth Sciences Data and Information Services Center (GES DISC) [data set], https://doi.org/10.5067/Aura/OMI/DATA2013, 2012.

Vömel, H. and Diaz, K.: Atmospheric Measurement Techniques Ozone sonde cell current measurements and implications for observations of near-zero ozone concentrations in the tropical upper troposphere, Atmos. Meas. Tech, 3, 495-505, https://doi.org/10.5194/amt-3-495-2010, 2010.

von der Gathen, P., Kivi, R., Wohltmann, I., Salawitch, R. J., and Rex, M.: Climate change favours large seasonal loss of Arctic ozone, Nat. Commun., 12, 3886, https://doi.org/10.1038/s41467021-24089-6, 2021.
Weber, M., Coldewey-Egbers, M., Fioletov, V. E., Frith, S. M., Wild, J. D., Burrows, J. P., Long, C. S., and Loyola, D.: Total ozone trends from 1979 to 2016 derived from five merged observational datasets - the emergence into ozone recovery, Atmos. Chem. Phys., 18, 2097-2117, https://doi.org/10.5194/acp18-2097-2018, 2018.

Weber, M., Arosio, C., Feng, W., Dhomse, S. S., Chipperfield, M. P., Meier, A., Burrows, J. P., Eichmann, K. U., Richter, A., and Rozanov, A.: The Unusual Stratospheric Arctic Winter 2019/20: Chemical Ozone Loss From Satellite Observations and TOMCAT Chemical Transport Model, J. Geophys. Res.-Atmos., 126, e2020JD034386, https://doi.org/10.1029/2020JD034386, 2021.

Wilka, C., Solomon, S., Kinnison, D., and Tarasick, D.: An Arctic Ozone Hole in 2020 If Not For the Montreal Protocol, Atmos. Chem. Phys. Discuss. [preprint], https://doi.org/10.5194/acp2020-1297, in review, 2021.

Wohltmann, I., von der Gathen, P., Lehmann, R., Maturilli, M., Deckelmann, H., Manney, G. L., Davies, J., Tarasick, D., Jepsen, N., Kivi, R., Lyall, N., and Rex, M.: Near-Complete Local Reduction of Arctic Stratospheric Ozone by Severe Chemical Loss in Spring 2020, Geophys. Res. Lett., 47, e2020GL089547, https://doi.org/10.1029/2020GL089547, 2020.

WMO (World Meteorological Organization): Scientific Assessment of Ozone Depletion: 2014, World Meteorological Organization, Global Ozone Research and Monitoring Project-Report No. 55, 416 pp., Geneva, Switzerland, 2014.

WMO (World Meteorological Organization): Scientific Assessment of Ozone Depletion: 2018, Global Ozone Research and Monitoring Project - Report No. 58, 588 pp., Geneva, Switzerland, 2018.

WMO/GAW: UV Radiation Monitoring Community, World Meteorological Organization-Global Atmosphere Watch Program (WMO-GAW)/World Ozone and Ultraviolet Radiation Data Centre (WOUDC) [data set], https://doi.org/10.14287/10000008, available at: https://woudc.org, last access: 24 August 2020. 